\title{
A comparative analysis of chiropractic and general practitioner patients in North America: Findings from the joint Canada/United States survey of health, 2002-03 \\ Eric L Hurwitz*1 and Lu-May Chiang ${ }^{2}$
}

\author{
Address: ${ }^{1}$ Department of Public Health Sciences and Epidemiology, John A. Burns School of Medicine, University of Hawaii - Manoa, 1960 East- \\ West Road, Biomed. D-104H, Honolulu, Hawaii 96822, USA and 2Department of Epidemiology, University of California - Los Angeles (UCLA) \\ School of Public Health, Los Angeles, California, USA \\ Email: Eric L Hurwitz* - ehurwitz@hawaii.edu; Lu-May Chiang - Imchiang@ucla.edu \\ * Corresponding author
}

Published: 06 April 2006

BMC Health Services Research2006, 6:49 doi:10.1 186/1472-6963-6-49

This article is available from: http://www.biomedcentral.com/l472-6963/6/49

(c) 2006Hurwitz and Chiang; licensee BioMed Central Ltd.

This is an Open Access article distributed under the terms of the Creative Commons Attribution License (http://creativecommons.org/licenses/by/2.0), which permits unrestricted use, distribution, and reproduction in any medium, provided the original work is properly cited.
Received: 28 December 2005

Accepted: 06 April 2006

\begin{abstract}
Background: Scientifically rigorous general population-based studies comparing chiropractic with primary-care medical patients within and between countries have not been published. The objective of this study is to compare care seekers of doctors of chiropractic (DCs) and general practitioners (GPs) in the United States and Canada on a comprehensive set of sociodemographic, quality of life, and health-related variables.
\end{abstract}

Methods: Data are from the Joint Canada/U.S. Survey of Health (JCUSH), 2002-03, a random sample of adults in Canada $(N=3505)$ and the U.S. $(N=5183)$. Respondents were categorized according to their pattern of health-care use in the past year. Distributions, percentages, and estimates (adjusted odds ratios) weighted to reflect the complex survey design were produced.

Results: Nearly $80 \%$ of respondents sought care from GPs; I $\%$ sought DC care. Compared with GP only patients, DC patients in both countries tend to be under 65 and white, with arthritis and disabling back or neck pain. U.S. DC patients are more likely than GP only patients to be obese and to lack a regular doctor; Canadian DC patients are more likely than GP only patients to be college educated, to have higher incomes, and dissatisfied with MD care. Compared with seekers of both GP and DC care, DC only patients in both countries have fewer chronic conditions, take fewer drugs, and have no regular doctor. U.S. DC only patients are more likely than GP+DC patients to be uninsured and dissatisfied with health care; Canadian DC only patients are more likely than GP+DC patients to be under 45, male, less educated, smokers, and not obese, without disabling back or neck pain, on fewer drugs, and lacking a regular doctor.

Conclusion: Chiropractic and GP patients are dissimilar in both Canada and the U.S., with key differences between countries and between DC patients who do and do not seek care from GPs. Such variation has broad and potentially far-reaching health policy and research implications.

\section{Background}

Chiropractic is the most commonly used unconventional therapy in Canada and the United States, both in the total populations and among primary care and family practice 
patients [1]. Back pain is one of the leading reasons for seeking general medical care and the top reason for visiting a chiropractor $[2,3]$. About $20 \%$ of the U.S. adult population has ever used chiropractic care, most commonly for low-back or neck pain [3]. In fact, the majority of all health-provider visits for low-back pain are to chiropractors, with patients reporting high levels of satisfaction and helpfulness [4,5]. However, little is known about the similarities and differences of persons who integrate chiropractic care with general medical care vs. those who consult chiropractors alone, either for musculoskeletal or neuromusculoskeletal problems, primary health care, disease prevention, or other reasons.

In recent studies of family practice and primary care patients, 20 to $30 \%$ report using some form of complementary or alternative medical (CAM) therapy, most commonly for back pain, other musculoskeletal pain, or for psychosocial problems or stress [6,7]. Chiropractic was the most popular method mentioned, followed by massage therapy, herbal therapies or supplements, and acupuncture. Research findings show that greater than 50\% of CAM users seek such care because they believe that CAM combined with conventional medical care would be helpful, suggesting that CAM does not substitute for conventional care. Three in 10 CAM users believe that conventional care alone would not be effective for their condition [3] and greater than six in 10 of CAM patients do not tell their physicians about their use of CAM $[8,9]$ and users of both CAM and conventional care for back or neck problems perceived CAM as more helpful than conventional care [9].

Although previous studies have compared chiropractic and medical patients, all have focused on care for specific conditions and in select geographic areas [10-15]. Multinational comparisons of all care seekers are of increasing relevance. Canada and the United States are countries with many similarities yet key differences in health-care policy and delivery. For example, the majority of medical doctors in Canada are in primary care, which is fully covered, whereas in the U.S., specialists outnumber primary care doctors, and lack of insurance is widespread [16]. Greater primary-care-to-specialist ratios have been associated with better population health indices [17].

The objective of the current study is to compare and contrast the socioeconomic and demographic, clinical and behavioral characteristics, and health-care perceptions of persons seeking care from chiropractors and general practitioners in the United States and Canada. The specific aims are to (1) estimate general practitioner and chiropractic utilization rates in Canada and the U.S., (2) identify factors associated with seeking (a) any chiropractic care vs. general practitioner care alone, and (b) chiroprac- tic care alone vs. general practitioner and chiropractic care in Canada and the U.S., and (3) identify between-country differences affecting the use of chiropractors vs. general practitioners.

\section{Methods}

Data source, subject selection, and target population

Public-use data from the Joint Canada/United States Survey of Health (JCUSH), 2002-03, were accessed and analyzed [18]. The JCUSH was a one-time stratified random sample telephone survey of non-institutionalized adult (aged 18 or greater) residents of Canada $(\mathrm{N}=3505)$ and the U.S. $(\mathrm{N}=5183)$ conducted between November 2002 and June 2003. Households were selected via a random digit dialing (RDD) process, and all interviews were conducted from the regional offices of Statistics Canada using the Computer-Assisted Telephone Interviewing (CATI) method [19]. The interview was administered in either French or English for Canadian respondents, and in either Spanish or English for U.S. respondents. The survey response rates were $66 \%$ and $50 \%$ in Canada and the U.S., respectively [19]. The target population was persons 18 years old or older residing in private dwellings with landline telephones in Canada and the U.S., excluding persons living in the territories of Canada or the U.S. The target population sizes in Canada and the U.S. were 24,046,837 and $206,417,185$, respectively $[20,21]$.

\section{Chiropractic and general practitioner utilization}

Respondents were queried about the number of visits to or contacts with various types of health professionals, including family doctors or general practitioners and chiropractors. Numbers of provider-specific visits per year were capped at 31 or more. Respondents within each country were categorized according to their type of reported health-care utilization in the past 12 months: any chiropractic care (DC), family doctor or general practitioner care only (GP), both DC and GP care, and DC without GP care.

\section{Socioeconomic and demographic factors}

Socioeconomic and demographic variables were age (1844, 45-64, >64), sex, race/ethnicity (white only, other/ multiple), marital status (married/with partner, widowed, separated/divorced, single), highest level of school completed or highest degree received (no high school degree, high school degree, some college, 4-year college degree), main source of income (employment vs. other), and amount of household income (adjusted for household size and placed in quintiles).

\section{Health status and reported chronic conditions}

Current general health status was assessed with several measures, including a 5-point measure of self-rated general health (excellent, very good, good, fair, poor), and 
presence of one or more chronic conditions (e.g., conditions that had lasted or were expected to last 6 months or more and had been diagnosed by a doctor or other health professional). Conditions included asthma, osteoarthritis, rheumatoid arthritis, hypertension, emphysema or chronic obstructive pulmonary disease, diabetes, heart disease, coronary heart disease, angina pectoris, and heart attack history. The reported chronic conditions were summed to create a chronic condition index ranging from 0 (no reported conditions) to 10 .

Mental health status, specifically depression, was assessed with a subset of questions from the Composite International Diagnostic Interview (CIDI) [22], which covers depressive disorder symptoms itemized in the Diagnostic and Statistical Manual of Mental Disorders (DSM-III-R) and produces diagnoses according to the Diagnostic Criteria for the Research of the ICD-10 [23]. Responses were transformed into a probability estimate of a diagnosis of major depressive episode (MDE) in the past 12 months. Respondents with estimates reflecting a $90 \%$ or greater certainty of a positive diagnosis ( 0.9 or greater) were classified as having had major depressive episodes in the past year [22-24]. Visits to mental health professionals were also tabulated.

Health-related quality of life was measured with the well validated Health Utility Index (HUI) [25]. The HUI includes components related to vision, hearing, speech, mobility, dexterity, emotions, cognition, and pain and discomfort [25].

\section{Activity restrictions and lifestyle factors affecting health}

The JCUSH included queries on restriction of activities (sometimes, often, never) due to one or more chronic health conditions, and activity limitations due to pain (no pain, pain but no activity limitations, pain prevents a few activities, pain prevents some activities, pain prevents most activities). Respondents were asked about the specific conditions or health problems responsible for any difficulties with performing activities of daily living, with back or neck problems among the specific response options. Respondents reporting pain rated the usual intensity of their pain or discomfort as being mild, moderate, or severe.

Respondents were asked about their smoking status, height and weight, and physical activity levels. Current smokers were those individuals who reported having smoked at least one whole cigarette and at the time of the survey smoked cigarettes every day. Each person's body mass index (BMI) was computed by dividing weight in kilograms by the square of height in meters. The World Health Organization's categories for classifying persons according to BMI are used [26]: underweight $(<18.5)$, nor- mal weight $(18.5-<25)$, overweight $(25-<30)$, and obese $(>=30)$. Activity-specific metabolic equivalent task (MET) scores $[27,28]$ and responses to questions about the frequency and duration of participation in leisure time physical activities in the past 3 months were used to compute total daily energy expenditure [29], which were then used to classify persons as being physically active $(>=3)$, moderately active $(1.5-<3)$, or inactive $(<1.5)$. Respondents were also classified according to their frequency of physical activity lasting more than 15 minutes in the past 3 months (regular $[>=12]$, occasional $[4-<12]$, infrequent $[<4])[30]$.

\section{Health-care utilization, perceived unmet needs, and satisfaction with care}

The JCUSH included several items on hospitalizations and the use of and visit frequency to medical doctors and other health care professionals in the past 12 months; prescription medication use in the past month and number of medications taken in the past 2 days; and in the U.S., health insurance status during the past 12 months. Respondents were also asked if they needed a health-care service in the past 12 months but didn't receive it because of lack of access, cost, or other reason (unmet health care need); and about their satisfaction with the overall quality of health care in the past 12 months, with physician care during their most recent visit (excellent, good, fair, poor), and the way health care services and physician care were provided (very satisfied, somewhat satisfied, neither satisfied nor dissatisfied, somewhat dissatisfied, very dissatisfied).

\section{Statistical methods}

Distributions and percentages weighted to reflect the complex survey design and nonresponse were produced according to each variable, stratified by pattern of healthcare use and country. The survey weight corresponds to the number of persons represented by the respondent for the target population [19]. Post-stratification using age, sex, region (Canada only), and race/ethnicity (U.S. only) was performed to ensure that the final weights sum to the population estimates, based on Canada's 1996 Census of Population [20] and the United States' October 2002 Current Population Survey [21]. SAS was used for data management and preliminary statistical analysis [31]. Because of the need to account for the complex survey design when estimating variances and confidence intervals, SUDAAN was used in modeling of associations and variance estimation [32]. SUDAAN uses the Taylor series method for estimation of variances.

Logistic regression modeling was employed to estimate crude and adjusted associations (odds ratios and 95\% confidence intervals) of each factor on care seeking from chiropractors vs. general practitioners. Specifically, two 
Table I: Frequency distributions (weighted percentages unless indicated otherwise) of socioeconomic, demographic, and health characteristics of respondents, and their health-care utilization, by country: Joint Canada/US Survey of Health, 2002-03*

\begin{tabular}{|c|c|c|c|c|c|}
\hline \multirow[b]{2}{*}{ Variable } & \multirow[b]{2}{*}{ Category } & \multicolumn{2}{|l|}{$\underline{\text { United States }}$} & \multicolumn{2}{|l|}{ Canada } \\
\hline & & $\begin{array}{l}\text { Any DC care } \\
(n=595)\end{array}$ & $\begin{array}{l}\text { Total pop. } \\
(\mathrm{N}=5 \mid 83)\end{array}$ & $\begin{array}{l}\text { Any DC care } \\
(n=448)\end{array}$ & $\begin{array}{l}\text { Total pop. } \\
(\mathrm{N}=3505)\end{array}$ \\
\hline \multicolumn{6}{|l|}{ Socioeconomic and demographic factors: } \\
\hline \multirow[t]{5}{*}{ Age (Years) } & $18-44$ & 50.3 & 52.3 & 56.4 & 52.3 \\
\hline & $45-64$ & 37.2 & 31.7 & 32.8 & 32.1 \\
\hline & $\geq 65$ & 12.5 & 16.0 & 10.8 & 15.6 \\
\hline & Mean (SE) & $45.2(0.7)$ & $45.4(0.3)$ & $43.4(0.8)$ & $45.1(0.3)$ \\
\hline & Median & 44 & 43 & 42 & 43 \\
\hline \multirow[t]{2}{*}{ Sex } & Male & 43.4 & 48.0 & 47.0 & 49.1 \\
\hline & Female & 56.6 & 52.0 & 53.0 & 50.9 \\
\hline \multirow[t]{2}{*}{ Race/ethnicity } & White only & 80.2 & 69.3 & 86.8 & 81.0 \\
\hline & Other/multiple & 16.7 & 26.4 & 13.0 & 17.7 \\
\hline \multirow[t]{4}{*}{ Education } & No high school degree or GED & 8.4 & 11.3 & I5.1 & 19.4 \\
\hline & High school degree or GED & 35.8 & 35.8 & 32.4 & 30.6 \\
\hline & Some college & 14.1 & 35.3 & 20.2 & 21.2 \\
\hline & 4-year college degree or certificate & 39.0 & 35.3 & 31.2 & 27.3 \\
\hline \multirow[t]{4}{*}{ Marital status } & Married or living with partner & 65.9 & 61.3 & 69.6 & 64.7 \\
\hline & Widowed & 4.6 & 6.1 & 3.9 & 5.7 \\
\hline & Separated or divorced & 11.4 & 10.4 & 7.8 & 7.7 \\
\hline & Single & 15.3 & 18.5 & 18.4 & 20.9 \\
\hline \multirow[t]{5}{*}{ Household income (adjusted for household size) } & Lowest quintile & 11.3 & 15.3 & 11.5 & 17.0 \\
\hline & Lower middle & 18.0 & 16.4 & 18.9 & 17.5 \\
\hline & Middle & 15.4 & 14.5 & 16.6 & 16.1 \\
\hline & Upper middle & 18.3 & 15.2 & 20.2 & 17.6 \\
\hline & Highest & 18.2 & 14.8 & 21.6 & 16.0 \\
\hline Main income source & Employment & 77.3 & 72.4 & 79.7 & 75.0 \\
\hline \multicolumn{6}{|l|}{ Health status and chronic conditions: } \\
\hline \multirow[t]{9}{*}{ Chronic conditions (lifetime history) } & Asthma & 13.1 & 11.4 & 12.3 & 10.4 \\
\hline & Arthritis & 23.2 & 18.6 & 20.3 & 16.8 \\
\hline & Hypertension & 19.9 & 22.7 & 13.0 & 18.3 \\
\hline & Emphysema or COPD & 1.8 & 2.1 & 1.2 & 1.3 \\
\hline & Diabetes & 5.1 & 6.7 & 3.9 & 4.7 \\
\hline & Heart disease & 4.7 & 6.0 & 4.5 & 5.1 \\
\hline & Coronary heart disease & 2.1 & 2.4 & 1.4 & 1.8 \\
\hline & Angina & 1.5 & 2.9 & 2.1 & 3.7 \\
\hline & I or more conditions & 38.4 & 36.8 & 34.2 & 33.4 \\
\hline Depression & Episode in past 12 months & 11.2 & 8.5 & 9.0 & 8.0 \\
\hline Mental health visit & Visit in past 12 months & 14.8 & 10.5 & 14.5 & 10.1 \\
\hline Emotional problems & Happy and interested in life & 77.7 & 77.9 & 84.8 & 80.8 \\
\hline Health Utility Index & Mean (SE) & $0.87(0.01)$ & $0.87(<0.01)$ & $0.87(0.01)$ & $0.88(<0.01)$ \\
\hline \multirow[t]{4}{*}{ Self-rated health } & Excellent & 26.1 & 26.4 & 23.5 & 24.0 \\
\hline & Very good & 36.9 & 32.5 & 39.1 & 36.4 \\
\hline & Good & 24.9 & 26.5 & 25.3 & 28.0 \\
\hline & Fair or poor & 12.1 & 14.6 & 12.2 & 11.5 \\
\hline \multicolumn{6}{|l|}{ Activity restrictions and lifestyle factors: } \\
\hline Pain/activity limits & No pain or discomfort & 75.2 & 80.6 & 75.3 & 82.0 \\
\hline \multirow[t]{3}{*}{ Activity restrictions } & Often & 9.9 & 10.1 & 10.0 & 9.6 \\
\hline & Sometimes & 24.4 & 18.6 & 25.4 & 19.8 \\
\hline & Never & 64.6 & 69.9 & 63.9 & 69.6 \\
\hline Back or neck problems & Cause of activity limitations & 16.3 & 9.1 & 20.1 & 10.4 \\
\hline \multirow[t]{3}{*}{ Smoking status } & Current & 19.7 & 22.3 & 23.6 & 24.8 \\
\hline & Past & 28.4 & 23.5 & 31.5 & 28.7 \\
\hline & Never & 51.5 & 53.7 & 44.7 & 46.2 \\
\hline Body weight & Under/normal weight $(\mathrm{BMI}<25)$ & 40.4 & 43.5 & 47.6 & 48.8 \\
\hline & Overweight (BMI $25-<30$ ) & 32.9 & 32.5 & 35.2 & 32.7 \\
\hline & Obese $(\mathrm{BMI}>=30)$ & 22.9 & 19.8 & 14.8 & 14.8 \\
\hline Physical activity (past 3 months) & Active & 22.0 & 21.1 & 27.0 & 26.4 \\
\hline & Moderate & 20.7 & 20.2 & 25.2 & 25.5 \\
\hline & Inactive & 55.2 & 55.9 & 46.9 & 47.0 \\
\hline
\end{tabular}


Table I: Frequency distributions (weighted percentages unless indicated otherwise) of socioeconomic, demographic, and health characteristics of respondents, and their health-care utilization, by country: Joint Canada/US Survey of Health, 2002-03* (Continued)

\begin{tabular}{|c|c|c|c|c|c|}
\hline \multirow[t]{3}{*}{ Activity frequency (past 3 months) } & Regular & 56.2 & 55.0 & 67.1 & 65.8 \\
\hline & Occasional & 18.3 & 16.9 & 18.4 & 16.4 \\
\hline & Infrequent & 23.5 & 25.2 & 13.7 & 16.7 \\
\hline \multicolumn{6}{|l|}{ Health-care use and perceptions: } \\
\hline Hospitalization & I or more in past 12 months & 10.3 & 10.2 & 7.7 & 9.1 \\
\hline No. of prescriptions & I or more in past month & 66.6 & 57.5 & 57.8 & 55.2 \\
\hline \multirow[t]{3}{*}{ No. of different prescription medications } & $<3$ in past 2 days & 47.3 & 37.5 & 44.4 & 39.9 \\
\hline & $3-5$ in past 2 days & 15.6 & 14.2 & 9.8 & 11.7 \\
\hline & $6+$ in past 2 days & 3.7 & 5.6 & 3.0 & 3.3 \\
\hline Health insurance & Insured in past 12 months & 89.2 & 86.9 & NA & NA7 \\
\hline Unmet health-care needs & Any in past 12 months & 12.5 & 13.1 & 11.6 & 10.7 \\
\hline Regular doctor & Yes in past 12 months & 84.3 & 79.5 & 89.2 & 84.7 \\
\hline \multirow{3}{*}{ Health care quality (past 12 months) } & Excellent & 41.6 & 38.2 & 33.6 & 36.5 \\
\hline & Good & 44.4 & 42.5 & 48.1 & 43.3 \\
\hline & Fair or poor & II.I & 10.5 & 16.7 & 13.9 \\
\hline \multirow[t]{3}{*}{ Health care satisfaction (past 12 months) } & Very satisfied & 50.8 & 48.5 & 41.2 & 40.8 \\
\hline & Somewhat satisfied & 35.9 & 33.3 & 40.7 & 40.4 \\
\hline & Less than satisfied & 10.3 & 9.1 & 16.1 & 12.1 \\
\hline \multirow{3}{*}{ Quality of MD care ${ }^{\dagger}$ (past 12 months) } & Excellent & 59.6 & 56.6 & 52.3 & 58.3 \\
\hline & Good & 32.6 & 32.6 & 36.0 & 33.1 \\
\hline & Fair or poor & 5.2 & 6.8 & II.I & 6.9 \\
\hline \multirow[t]{3}{*}{ Satisfaction of MD care ${ }^{\dagger}$ (past 12 months) } & Very satisfied & 69.2 & 65.2 & 61.0 & 64.8 \\
\hline & Somewhat satisfied & 23.2 & 25.7 & 29.2 & 27.0 \\
\hline & Less than satisfied & 4.2 & 4.8 & 8.9 & 6.1 \\
\hline \multirow[t]{5}{*}{ Health-care use $\ddagger$ (past 12 months) } & Any chiropractic care & 100 & 11.4 & 100 & 12.9 \\
\hline & GP care only & 0 & 67.2 & 0 & 68.8 \\
\hline & Both GP and DC care & 85.3 & 9.7 & 87.7 & 11.3 \\
\hline & Chiropractic care only & 14.7 & 1.7 & 13.3 & 1.6 \\
\hline & No GP or DC care & 0 & 20.7 & 0 & 17.5 \\
\hline \multirow[t]{8}{*}{ Chiropractic visits (past 12 months) } & 0 & 0 & 88.5 & 0 & 86.8 \\
\hline & 1 & 20.9 & 2.4 & 14.7 & 1.9 \\
\hline & $2-5$ & 34.9 & 4.0 & 34.1 & 4.4 \\
\hline & $6-10$ & 15.8 & 1.8 & 20.4 & 2.6 \\
\hline & $11-20$ & 18.0 & 2.1 & 19.5 & 2.5 \\
\hline & $21-30$ & 4.6 & 0.5 & 6.8 & 0.9 \\
\hline & $31+$ & 5.8 & 0.7 & 4.5 & 0.6 \\
\hline & Mean, median & $8.22,4$ & $0.94,0$ & $8.80,5$ & $1.14,0$ \\
\hline \multirow{8}{*}{$\begin{array}{l}\text { General practitioner or family doctor visits (past } \\
12 \text { months) }\end{array}$} & 0 & 14.7 & 22.5 & 12.3 & 19.1 \\
\hline & 1 & 22.4 & 22.8 & 19.8 & 21.8 \\
\hline & $2-5$ & 50.0 & 41.8 & 49.7 & 42.8 \\
\hline & $6-10$ & 8.2 & 7.4 & 9.0 & 7.9 \\
\hline & $11-20$ & 2.7 & 3.9 & 8.0 & 6.6 \\
\hline & $21-30$ & I.I & 0.7 & 1.0 & 0.7 \\
\hline & $31+$ & 0.9 & 0.5 & 0.2 & 0.5 \\
\hline & Mean, median & $3.18,2$ & $2.84,2$ & $3.69,2$ & $3.31,2$ \\
\hline \multirow[t]{8}{*}{ All health-care visits (past 12 months) } & 0 & 0 & 6.9 & 0 & 5.2 \\
\hline & 1 & 0.7 & 7.3 & 0.9 & 7.9 \\
\hline & $2-5$ & 14.6 & 38.6 & 11.4 & 39.0 \\
\hline & $6-10$ & 24.1 & 22.1 & 22.4 & 22.3 \\
\hline & $11-20$ & 28.7 & 15.3 & 32.3 & 15.5 \\
\hline & $21-30$ & 14.7 & 4.9 & 17.6 & 5.7 \\
\hline & $31+$ & 17.2 & 4.9 & 15.5 & 4.5 \\
\hline & Mean, median & $17.11,14$ & $8.69,5$ & $17.97,15$ & $8.66,5$ \\
\hline
\end{tabular}

\footnotetext{
* Weighted percentages may not sum to 100 because of missing data or exclusion of certain categories; percentages weighted to account for age, sex, region (Canada only), and race/ethnicity (U.S. only); 595 and 5183 represent 23,513,576 and 206,417,185 adults, respectively, in the U.S.; 448 and 3505 represent 3,105,017 and 24,046,837 adults, respectively, in Canada.

† Most recent visit among respondents reporting at least one visit to a physician in the past 12 months.

$¥$ Weighted percentages sum to greater than 100 because categories are not mutually exclusive.

$D C=$ Doctor of Chiropractic; $S E$ = standard error; $C O P D=$ chronic obstructive pulmonary disease; $B M I$ = body mass index; NA = not applicable; $\mathrm{GP}=$ general practitioner or family doctor; $\mathrm{MD}=$ medical doctor.
} 
Table 2: Frequency distributions (weighted percentages unless indicated otherwise) of socioeconomic and demographic characteristics of DC and GP patients, by country and pattern of health-care use in the past 12 months: Joint Canada/US Survey of Health, 2002-03*

\begin{tabular}{|c|c|c|c|c|c|c|c|}
\hline \multirow[b]{2}{*}{ Variable } & \multirow[b]{2}{*}{ Category } & \multicolumn{3}{|c|}{ United States } & \multicolumn{3}{|l|}{ Canada } \\
\hline & & $\begin{array}{l}\text { GP only } \\
(\mathrm{n}=3565)\end{array}$ & $\begin{array}{l}G P+D C \\
(n=5 I I)\end{array}$ & $\begin{array}{l}\text { DC only } \\
(\mathrm{n}=84)\end{array}$ & $\begin{array}{l}\text { GP only } \\
(n=2434)\end{array}$ & $\begin{array}{l}\text { GP+DC } \\
(n=397)\end{array}$ & $\begin{array}{l}\text { DC only } \\
(n=5 I)\end{array}$ \\
\hline \multirow[t]{5}{*}{ Age (Years) } & $18-44$ & 47.8 & 47.6 & 65.7 & 48.5 & 53.0 & 81.1 \\
\hline & $45-64$ & 33.0 & 38.8 & 28.3 & 32.8 & 35.2 & 15.6 \\
\hline & $\geq 65$ & 19.2 & 13.6 & 6.1 & 18.7 & 11.8 & 3.3 \\
\hline & Mean (SE) & $47.2(0.3)$ & $46.1(0.8)$ & $40.3(1.4)$ & $46.5(0.4)$ & $44.6(0.8)$ & $34.4(2.0)$ \\
\hline & Median & 45 & 45 & 38 & 45 & 43 & 33 \\
\hline \multirow[t]{2}{*}{ Sex } & Male & 45.1 & 42.2 & 50.5 & 45.5 & 42.7 & 77.2 \\
\hline & Female & 54.9 & 57.8 & 49.5 & 54.5 & 57.3 & 22.8 \\
\hline \multirow[t]{2}{*}{ Race/ethnicity } & White only & 68.9 & 81.4 & 73.3 & 80.1 & 86.9 & 85.5 \\
\hline & Other/multiple & 26.7 & 15.4 & 24.1 & 18.4 & 12.8 & 14.5 \\
\hline \multirow[t]{4}{*}{ Education } & No H.S. degree & 10.8 & 8.0 & 10.4 & 20.7 & 13.9 & 23.3 \\
\hline & High school degree & 35.4 & 35.1 & 39.6 & 29.2 & 31.5 & 38.4 \\
\hline & Some college & 13.9 & 13.0 & 20.0 & 21.7 & 20.0 & 22.1 \\
\hline & 4-year college degree 35.6 & 41.1 & 27.3 & 27.0 & 33.3 & 16.1 & \\
\hline \multirow[t]{4}{*}{ Marital status } & Married/with partner & 61.8 & 66.2 & 64.0 & 64.9 & 70.9 & 60.6 \\
\hline & Widowed & 7.1 & 4.6 & 4.1 & 6.7 & 4.5 & 0.0 \\
\hline & Separated/divorced & 10.3 & 11.5 & 10.8 & 7.5 & 8.5 & 2.8 \\
\hline & Single & 16.9 & 14.8 & 18.5 & 19.7 & 15.9 & 36.6 \\
\hline \multirow{5}{*}{$\begin{array}{l}\text { Household income (adjusted for } \\
\text { household size) }\end{array}$} & Lowest quintile & 14.8 & 10.5 & 15.5 & 18.2 & 11.5 & 11.6 \\
\hline & Lower middle & 16.3 & 18.4 & 15.8 & 17.0 & 18.2 & 24.2 \\
\hline & Middle & 15.1 & 15.7 & 13.7 & 16.6 & 16.2 & 19.5 \\
\hline & Upper middle & 14.8 & 18.7 & 15.9 & 16.9 & 20.6 & 16.9 \\
\hline & Highest & 14.9 & 18.5 & 16.8 & 15.2 & 22.8 & 13.1 \\
\hline Main income source & Employment & 69.6 & 76.5 & 82.1 & 71.6 & 79.4 & 82.0 \\
\hline
\end{tabular}

* Weighted percentages may not sum to 100 because of missing data or exclusion of certain categories; percentages weighted to account for age, sex, region (Canada only), and race/ethnicity (U.S. only); 3565, $5 \mathrm{II}$, and 84 represent I38,802,5I 9, 20,060,4I2, and 3,453, 164 adults, respectively, in the U.S.; 2434, 397, and 5 I represent 16,555,7I9, 2,723,870, and 38I,147 adults, respectively, in Canada.

$\mathrm{GP}=$ general practitioner or family doctor; $\mathrm{DC}=$ Doctor of Chiropractic; $\mathrm{SE}=$ standard error.

sets of crude and adjusted models were run: one to estimate associations of potential predictors with any chiropractic care vs. general practitioner care only, and another to estimate associations of potential predictors with chiropractic care only vs. both chiropractic and general practitioner care. Sets of one or more binary (dummy) variables were used to model the effects of all predictors, with the exceptions of the health utility, chronic condition, and prescription medication indices, which were modeled as continuous variables, and age, which was modeled as both a categorical and a continuous predictor. Potential between-country differences in effect estimates were evaluated by the inclusion of interaction terms in additional sets of multivariable models.

Potential confounders were identified a priori as those measured variables thought to be predictors of type of health-care use and possibly associated with one or more of the selected variables of interest. Because of inherent multidirectional relations (e.g., variables acting as both causes and consequences of certain predictors and/or health-care use) and lack of longitudinal data, two sets of separate multivariable logistic regression models were built to estimate adjusted associations. In addition to the selected variable (e.g., potential predictor), one set of models included only age, sex, and race/ethnicity. The second set included these variables plus education, main source of income, health-related quality of life (HUI), and health insurance status (U.S. only).

To assess the sensitivity of estimates to method of healthstatus measurement and to avoid multicollinearity, alternative models replaced the HUI with self-rated general health, chronic condition index score, and activity limitations due to pain. Because replacing the HUI with each of these variables, alone and in combination, did not materially change the odds ratios, these effect estimates are not presented.

\section{Human subjects}

The JCUSH design, questionnaires, and informed consent, interview and all other survey-related protocols were reviewed and approved by the Institutional Review Boards of Statistics Canada and the United States National Center for Health Statistics [19]. Because all direct identifiers, plus any characteristics that could possibly lead to the 
Table 3: Frequency distributions (weighted percentages unless indicated otherwise) of health status variables and chronic conditions reported by DC and GP patients, by country and pattern of health-care use in the past 12 months: Joint Canada/US Survey of Health, 2002-03*

\begin{tabular}{|c|c|c|c|c|c|c|c|}
\hline \multirow[b]{2}{*}{ Variable } & \multirow[b]{2}{*}{ Category } & \multicolumn{3}{|l|}{ United States } & \multicolumn{3}{|l|}{ Canada } \\
\hline & & $\begin{array}{l}\text { GP only } \\
(\mathrm{n}=3565)\end{array}$ & $\begin{array}{l}\text { GP+DC } \\
(n=5 I I)\end{array}$ & $\begin{array}{l}\text { DC only } \\
(\mathrm{n}=84)\end{array}$ & $\begin{array}{l}\text { GP only } \\
(n=2434)\end{array}$ & $\begin{array}{l}G P+D C \\
(n=397)\end{array}$ & $\begin{array}{l}\text { DC only } \\
(\mathrm{n}=5 \mathrm{I})\end{array}$ \\
\hline Health Utility Index & Mean (SE) & $0.86(<0.01)$ & $0.87(0.01)$ & $0.87(0.02)$ & $0.88(0.01)$ & $0.87(0.01)$ & $0.92(0.02)$ \\
\hline \multirow[t]{4}{*}{ Self-rated health } & Excellent & 23.4 & 25.3 & 30.7 & 20.8 & 21.5 & 38.0 \\
\hline & Very good & 32.7 & 38.5 & 27.7 & 36.9 & 39.6 & 35.4 \\
\hline & Good & 27.3 & 23.4 & 34.0 & 29.3 & 25.3 & 24.7 \\
\hline & Fair or poor & 16.6 & 12.8 & 7.6 & 12.9 & 13.6 & 2.0 \\
\hline Depression & Episode, past year & 8.7 & 11.2 & 11.6 & 8.5 & 9.8 & 3.5 \\
\hline Mental health visit & Visit, past year & 11.8 & 16.1 & 7.5 & 11.1 & 16.5 & 0.0 \\
\hline Emotional problems & Happy in life & 78.0 & 77.4 & 79.0 & 80.3 & 84.9 & 84.0 \\
\hline \multirow[t]{9}{*}{ Chronic conditions (lifetime history) } & Asthma & 12.0 & 14.8 & 3.3 & 10.8 & 12.5 & 10.4 \\
\hline & Arthritis & 21.3 & 24.2 & 17.8 & 19.1 & 23.2 & 0.0 \\
\hline & Hypertension & 27.4 & 22.7 & 3.5 & 22.0 & 14.4 & 2.5 \\
\hline & Emphysema or COPD 2.6 & 2.0 & 0.7 & 1.6 & 1.4 & 0.0 & \\
\hline & Diabetes & 8.6 & 6.0 & 0.0 & 5.8 & 4.3 & 0.7 \\
\hline & Heart disease & 7.5 & 5.0 & 3.0 & 6.2 & 5.0 & 1.0 \\
\hline & Coronary heart disease 3.1 & 2.3 & 0.6 & 2.3 & 1.4 & 1.0 & \\
\hline & Angina & 3.6 & 1.4 & 2.5 & 4.8 & 2.4 & 0.0 \\
\hline & I or more conditions & 43.1 & 41.7 & 19.1 & 38.2 & 37.9 & 8.2 \\
\hline
\end{tabular}

* Weighted percentages may not sum to 100 because of missing data or exclusion of certain categories; percentages weighted to account for age, sex, region (Canada only), and race/ethnicity (U.S. only); 3565, $5 \mathrm{II}$, and 84 represent I38,802,5 I9, 20,060,4I2, and 3,453, 164 adults, respectively, in the U.S.; 2434, 397, and 51 represent 16,555,719, 2,723,870, and 38I, 147 adults, respectively, in Canada.

$\mathrm{GP}=$ general practitioner or family doctor; $\mathrm{DC}=$ Doctor of Chiropractic $\mathrm{SE}=$ standard error; $\mathrm{COPD}=$ chronic obstructive pulmonary disease

identity of any individual respondent, are removed from the public-use data files, which can only be used for statistical research and data analysis, and cannot be linked to any other individually identifiable data, the project qualified for exemption from coverage by the Human Subjects regulations.

\section{Results \\ Frequency of chiropractic and general practitioner care in Canada and the U.S}

Table 1 shows the sociodemographics, health characteristics, and health-care utilization of (1) all respondents and (2) respondents reporting any chiropractic care, by country. In both the U.S. and Canada, about $12 \%$ of adults seek chiropractic care annually, nearly $80 \%$ seek GP care, twothirds seek GP care and no chiropractic care, about $10 \%$ visit both chiropractors and general practitioners, and fewer than $2 \%$ seek only chiropractic care. Estimated DC visit rates in the U.S. and Canada are 0.94 and 1.14 per 100 person-years, respectively. General practitioner visit rates are 2.84 and 3.31 per 100 person-years in the U.S. and Canada, respectively.

\section{DC vs. GP patient comparisons}

Socioeconomic and demographic factors

Table 2 shows the distributions of socioeconomic and demographic characteristics of DC and GP patients, by country. Compared with GP only patients in both the U.S. and Canada, GP patients who also saw DCs are younger and more likely to be white, female, married, college educated, in the highest income quintile, and to report employment as their main income source. Compared with persons who sought care from both GPs and DCs, DC only patients in both countries tend to be younger, male, single, less educated, to have lower incomes, and to report employment as their main income source.

\section{Health status and reported chronic conditions}

Table 3 gives the distributions of general and mental health status, and frequencies of chronic conditions reported by DC and GP patients, by country. Compared with GP only patients, GP patients who also saw DCs in the U.S. and Canada are more likely to be in very good or excellent self-reported health and to have fewer chronic health conditions, but more likely to report histories of asthma and/or arthritis. DC patients in the U.S. are more likely to have had a depressive episode and mental health visits in the past year, whereas Canadian DC patients were more likely than their GP counterparts to have mental health visits and to be happy and interested in life. Compared with persons who sought care from both GPs and DCs, DC only patients in both countries tend to have fewer chronic health conditions. 
Activity restrictions, weight, smoking, and physical activity

Table 4 compares DC and GP patients on variables related to activity restrictions, body weight, smoking, and physical activity, by country. Compared with GP only patients, GP patients who also saw DCs in the U.S. and Canada are more likely to have had activity-limiting back or neck problems in the past year. Compared with persons who sought care from both GPs and DCs, DC only patients tend to have less activity-limiting back or neck pain, and fewer activity restrictions. Most patients in the U.S., regardless of pattern of care seeking, are overweight or obese, never smokers, and physically inactive. Canadian patients are somewhat less likely than U.S. patients to be overweight or obese, never smokers, and physically inactive.

\section{Health-care use and perceptions}

Table 5 compares DC and GP patients on health-care and prescription-medication use, satisfaction with care and with providers, and unmet health-care needs, by country. Overall visit rates vary dramatically according to whether persons seek care from a DC or a GP, though GP visit rates were similar among GP patients who sought and did not seek chiropractic care, suggesting that chiropractic visits did not substitute for GP visits among these patients. However, compared with GP patients who did not seek chiropractic care, GP patients with chiropractic visits had on average almost 1.5 more visits to other health-care providers in both Canada and the U.S. Conversely, chiropractic patients with no GP visits had fewer visits, on average, to other health-care providers.

Compared with GP only patients, Canadian GP patients who also saw DCs reported greater dissatisfaction with their overall health and physician care. In the U.S., patients who saw GPs only and those who saw both GPs and DCs were comparable to each other in these and other health-care respects, including reported unmet health-care needs, which are greater overall in the U.S. than in Canada. Compared with persons who sought care from both GPs and DCs, DC only patients in both countries were less likely to have been hospitalized in the past year, less likely to use prescription drugs, less likely to have a regular doctor, more dissatisfied with their overall health care, and in the U.S., more likely uninsured.

\section{Factors associated with chiropractic vs. general practitioner care in Canada and the U.S}

Tables 6 and 7 show the estimated crude and adjusted associations of socioeconomic and demographic, quality of life, and health-related factors on seeking in the past 12 months (1) any chiropractic care vs. GP only care and (2) chiropractic care only vs. both GP and DC care among U.S. (Table 6) and Canadian (Table 7) respondents. The age-sex-race/ethnicity-adjusted estimates (Model 1) were mostly unaffected by the additional control of education, main source of income, health-related quality of life, and (in the U.S.) health insurance status (Model 2).

Factors associated with seeking chiropractic care vs. GP care alone in the U.S. are being less than 65 years old and white; having arthritis, bodily pain, and activity limitations due to back or neck pain; being obese, and lacking a regular doctor. Canadian chiropractic care seekers, compared with GP patients, tend to be under 65, white, and college educated; report higher incomes and greater happiness with life; have arthritis, bodily pain, and activity limitations due to back or neck pain; and perceive the quality of physician care to be fair or poor, and to not be satisfied with it.

Adjusted effect estimates (odds ratios) of factors on seeking any DC care vs. GP only care that vary appreciably by country (U.S. vs. Canada) are having a regular doctor ( 0.59 vs. $0.95, P=0.08)$, perceiving health care quality as good $(0.93$ vs. $1.24, P=0.09)$ or fair or poor $(0.95$ vs. $1.36, P=0.15)$ vs. excellent, perceiving quality of MD care as good (0.94 vs. $1.23, P=0.14)$ or fair or poor $(0.71 \mathrm{vs.}$ $2.25, P=0.0008)$ vs. excellent, and being somewhat satisfied $(0.77$ vs. $1.17, P=0.04)$ or not satisfied $(0.72$ vs. 1.65 , $P=0.02)$ vs. very satisfied with MD care.

Compared with persons who sought care from both GPs and DCs in the U.S., DC only patients are relatively younger, with no or few chronic conditions, on no or few prescription medications, to have no regular doctor, no health insurance, and to express dissatisfaction with the quality of health care. Factors associated with DC only vs. DC and GP care among Canadian respondents are age less than 45, being male, and lacking a college degree; having better self-rated health, no or few chronic conditions, and no bodily pain or activity limitations due to back or neck pain; being a current smoker, not obese, and infrequently physically active; taking no or few prescription drugs and lacking a regular doctor.

Adjusted effect estimates (odds ratios) of factors on seeking DC care only vs. GP and DC care that vary appreciably by country (U.S. vs. Canada) are 10-year age increment (0.90 vs. $0.61, P=0.10)$, male sex ( 1.34 vs. $3.63, P=0.04)$, fair or poor vs. excellent self-rated health $(0.69$ vs. $0.09, P$ $=0.11)$, depression in the past year (1.08 vs. $0.39, P=$ $0.15)$, pain-related activity limitations ( 1.12 vs. $0.30, P=$ $0.06)$, disabling back or neck problems (1.04 vs. $0.19, P=$ 0.07 ), past ( 1.32 vs. $0.22, P=0.01)$ and current (0.68 vs. 2.13, $P=0.03$ ) smoking, being overweight (1.64 vs. 0.55 , $P=0.15)$, infrequent physical activity $(1.11$ vs. $2.42, P=$ $0.13)$, and having a regular doctor $(0.09$ vs. $0.25, P=$ $0.08)$. 
Table 4: Frequency distributions (weighted percentages) of variables related to activity restrictions, body weight, smoking, and physical activity, by country and pattern of health-care use in the past 12 months: Joint Canada/US Survey of Health, 2002-03*

\begin{tabular}{|c|c|c|c|c|c|c|c|}
\hline \multirow[b]{2}{*}{ Variable } & \multirow[b]{2}{*}{ Category } & \multicolumn{3}{|c|}{ United States } & \multicolumn{3}{|l|}{ Canada } \\
\hline & & $\begin{array}{l}\text { GP only } \\
(n=3565)\end{array}$ & $\begin{array}{l}G P+D C \\
(n=5 I I)\end{array}$ & $\begin{array}{l}\text { DC only } \\
(n=84)\end{array}$ & $\begin{array}{l}\text { GP only } \\
(n=2434)\end{array}$ & $\begin{array}{l}\text { GP+DC } \\
(n=397)\end{array}$ & $\begin{array}{l}\text { DC only } \\
(n=5 I)\end{array}$ \\
\hline Pain/activity limits & No pain/discomfort & 79.3 & 74.5 & 79.7 & 81.0 & 73.2 & 90.3 \\
\hline \multirow[t]{3}{*}{ Activity restrictions } & Often & 11.5 & 10.7 & 5.6 & 11.0 & 10.4 & 6.7 \\
\hline & Sometimes & 19.7 & 24.6 & 23.5 & 20.2 & 27.3 & 12.3 \\
\hline & Never & 67.3 & 63.6 & 70.2 & 67.8 & 61.8 & 79.4 \\
\hline Back/neck problems & Activity limiting & 8.9 & 16.9 & 12.8 & 10.0 & 22.2 & 5.5 \\
\hline \multirow[t]{3}{*}{ Smoking status } & Current & 20.8 & 20.4 & 15.7 & 24.0 & 19.9 & 49.6 \\
\hline & Past & 24.6 & 28.3 & 29.1 & 29.2 & 34.8 & 7.6 \\
\hline & Never & 54.0 & 50.9 & 55.2 & 46.5 & 44.9 & 42.9 \\
\hline \multirow[t]{3}{*}{ Body weight } & Under/normal weight & 42.5 & 40.9 & 37.7 & 48.7 & 46.5 & 55.5 \\
\hline & Overweight & 32.4 & 31.4 & 41.6 & 32.3 & 35.4 & 34.1 \\
\hline & Obese & 20.8 & 23.7 & 18.3 & 15.4 & 15.7 & 8.6 \\
\hline \multirow[t]{3}{*}{ Physical activity (past 3 months) } & Active & 20.4 & 22.6 & 18.5 & 25.7 & 27.8 & 21.5 \\
\hline & Moderate & 20.0 & 21.2 & 18.2 & 26.3 & 25.7 & 21.7 \\
\hline & Inactive & 56.5 & 54.3 & 60.7 & 47.0 & 45.6 & 56.8 \\
\hline \multirow[t]{3}{*}{ Activity frequency (past 3 months) } & Regular & 55.6 & 56.1 & 56.5 & 66.3 & 68.3 & 58.6 \\
\hline & Occasional & 16.1 & 19.2 & 13.2 & 15.8 & 18.6 & 17.4 \\
\hline & Infrequent & 25.2 & 22.8 & 27.7 & 16.8 & 12.2 & 24.0 \\
\hline
\end{tabular}

* Weighted percentages may not sum to 100 because of missing data or exclusion of certain categories; percentages weighted to account for age, sex, region (Canada only), and race/ethnicity (U.S. only); 3565, 5I I, and 84 represent I38,802,5I9, 20,060,4I2, and 3,453, I64 adults, respectively, in the U.S.; 2434, 397, and 5 I represent 16,555,719, 2,723,870, and 38I, I47 adults, respectively, in Canada.

$\mathrm{GP}=$ general practitioner or family doctor; DC $=$ Doctor of Chiropractic.

\section{Discussion}

This is the first study, to our knowledge, using nationallyrepresentative samples from more than one country and the same survey methods and measures to (1) document the similarities and differences of persons seeking care from general practitioners and those seeking care from chiropractors, alone or in conjunction with GP care, and (2) provide mutually comparable estimates of chiropractic and GP visit rates. The only other study to estimate chiropractic visit rates in the U.S. and Canada found the visit rates to be 101.2 and 140.9 per 100 person years, respectively [33]. These estimates are derived from 5 sites in the U.S. and from Toronto, Ontario, Canada, and thus may not be entirely representative of the national populations. Because the JCUHS capped the annual number of provider-specific visits at 31 or more, our lower estimates of 0.94 and 1.14 per 100 person-years, respectively, are conservative and likely somewhat less than the true chiropractic visit rates in each country, however.

Extrapolating to the adult populations of the U.S. and Canada, approximately 23.5 million adults in the U.S. and 3.1 million adults in Canada had at least one chiropractic visit in the past year. Although the vast majority of chiropractic patients also sought care from primary-care medical doctors, about 3.5 million chiropractic patients in the U.S. and almost 400,000 in Canada did not seek care from general or family practitioners, suggesting that chiropractors may be delivering or in the position to deliver primary health care to an appreciable number of people, and indicating the need for chiropractors to be knowledgeable and cognizant of problems that may require medical referral. More than $50 \%$ of these patients in the U.S. and $35 \%$ in Canada reported not having a regular doctor. Large proportions of chiropractic patients have chronic conditions, recent episodes of depression, and reported use of prescription medications, underscoring the importance for chiropractors in taking thorough health and medication inventories, querying about possible drug side effects and interactions, offering drug-free alternatives to their patients, and integrating chiropractic with conventional medical care [34]. Given that persons seeking chiropractic care are just as likely as others to smoke and be overweight or obese and sedentary, the role for chiropractic in encouraging health promotion and disease prevention activities also cannot be underestimated [35].

Differences in the characteristics of persons seeking care from chiropractors alone vs. care from both medical and chiropractic providers are notable. For example, persons seeking care from chiropractors are more likely than those seeking primary medical care to have activity limitations due to back or neck pain. However, persons seeking only chiropractic care in Canada are less likely to have activitylimiting back or neck pain, more likely uninsured in the U.S., and in both countries, much less likely to have chronic conditions and to have a regular doctor. These dif- 
Table 5: Frequency distributions (weighted percentages) of health-care and prescription-medication use, satisfaction with care and with providers, and unmet health-care needs, by country and pattern of health-care use in the past I 2 months: Joint Canada/US Survey of Health, 2002-03*

\begin{tabular}{|c|c|c|c|c|c|c|c|}
\hline \multirow[b]{2}{*}{ Variable } & \multirow[b]{2}{*}{ Category } & \multicolumn{3}{|c|}{ United States } & \multicolumn{3}{|l|}{ Canada } \\
\hline & & $\begin{array}{l}\text { GP only } \\
(\mathrm{n}=3565)\end{array}$ & $\begin{array}{l}G P+D C \\
(n=51 I)\end{array}$ & $\begin{array}{l}\text { DC only } \\
(\mathrm{n}=84)\end{array}$ & $\begin{array}{l}\text { GP only } \\
(\mathrm{n}=2434)\end{array}$ & $\begin{array}{l}\text { GP+DC } \\
(n=397)\end{array}$ & $\begin{array}{l}\text { DC only } \\
(n=51)\end{array}$ \\
\hline Hospitalization & I+ in past year & 11.7 & 11.3 & 4.6 & 10.7 & 8.1 & 5.3 \\
\hline No. of prescriptions & I+ in past month & 67.2 & 72.2 & 34.1 & 64.2 & 63.3 & 18.4 \\
\hline \multirow[t]{3}{*}{ No. of different prescription medications } & $<3$ in past 2 days & 42.2 & 50.0 & 31.7 & 45.4 & 48.1 & 17.8 \\
\hline & $3-5$ in past 2 days & 17.5 & 17.9 & 1.8 & 14.6 & 11.0 & 0.7 \\
\hline & $6+$ in past 2 days & 7.2 & 4.3 & 0.6 & 4.1 & 3.4 & 0.0 \\
\hline Health insurance & Insured, past year & 90.8 & 92.1 & 72.9 & NA & NA & NA \\
\hline Unmet needs & Any in past year & 12.2 & 12.7 & 11.1 & 11.0 & 11.8 & 10.3 \\
\hline Regular doctor & Yes in past year & 89.8 & 90.8 & 46.1 & 91.4 & 92.5 & 65.0 \\
\hline \multirow[t]{3}{*}{ Health care quality (past 12 months) } & Excellent & 40.4 & 42.6 & 36.2 & 39.1 & 35.6 & 19.6 \\
\hline & Good & 45.7 & 43.2 & 51.5 & 45.9 & 47.2 & 54.5 \\
\hline & Fair or poor & 11.3 & II.I & 11.0 & 13.8 & 16.0 & 21.9 \\
\hline \multirow[t]{3}{*}{ Health care satisfaction (past 12 months) } & Very satisfied & 52.0 & 53.2 & 36.8 & 43.4 & 43.1 & 27.2 \\
\hline & Somewhat satisfied & 35.5 & 34.9 & 41.9 & 42.7 & 40.4 & 42.8 \\
\hline & Less than satisfied & 9.7 & 8.6 & 20.0 & 12.3 & 14.7 & 26.0 \\
\hline \multirow[t]{3}{*}{ Quality of MD care ${ }^{\dagger}$ (past 12 months) } & Excellent & 56.7 & 58.4 & 71.5 & 59.7 & 52.5 & 47.8 \\
\hline & Good & 32.7 & 33.9 & 19.1 & 33.0 & 35.9 & 38.2 \\
\hline & Fair or poor & 7.1 & 5.0 & 7.8 & 5.8 & 10.9 & 14.0 \\
\hline \multirow[t]{3}{*}{ Satisfaction of MD† care (past 12 months) } & Very satisfied & 65.5 & 70.2 & 59.0 & 65.9 & 61.2 & 56.2 \\
\hline & Somewhat satisfied & 26.2 & 22.1 & 35.0 & 27.0 & 29.2 & 29.9 \\
\hline & Less than satisfied & 4.7 & 4.2 & 4.4 & 5.3 & 8.7 & 14.0 \\
\hline \multirow{8}{*}{ Chiropractic visits (past 12 months) } & 0 & 100 & 0 & 0 & 100 & 0 & 0 \\
\hline & 1 & & 20.6 & 23.2 & & 13.8 & 21.6 \\
\hline & $2-5$ & & 34.3 & 38.2 & & 33.8 & 35.7 \\
\hline & $6-10$ & & 16.8 & 10.2 & & 20.9 & 16.9 \\
\hline & $11-20$ & & 17.3 & 22.2 & & 19.3 & 20.2 \\
\hline & $21-30$ & & 5.3 & 0 & & 7.3 & 3.2 \\
\hline & $31+$ & & 5.8 & 6.2 & & 4.8 & 2.5 \\
\hline & Mean, median & & $8.36,4$ & $7.42,3$ & & $9.01,5$ & $7.29,3$ \\
\hline \multirow{8}{*}{$\begin{array}{l}\text { General practitioner or family doctor visits } \\
\text { (past } 12 \text { months) }\end{array}$} & 0 & 0 & 0 & 100 & 0 & 0 & 100 \\
\hline & I & 30.0 & 26.3 & & 27.9 & 22.6 & \\
\hline & $2-5$ & 53.7 & 58.6 & & 52.8 & 56.7 & \\
\hline & $6-10$ & 9.6 & 9.7 & & 9.8 & 10.2 & \\
\hline & $11-20$ & 5.3 & 3.1 & & 8.0 & 9.2 & \\
\hline & $21-30$ & 0.8 & 1.3 & & 0.8 & 1.2 & \\
\hline & $31+$ & 0.7 & 1.0 & & 0.8 & 0.2 & \\
\hline & Mean, median & $3.66,2$ & $3.73,2$ & & $4.08,2$ & $4.21,3$ & \\
\hline \multirow{8}{*}{ All health-care visits (past 12 months) } & 0 & 0 & 0 & 0 & 0 & 0 & 0 \\
\hline & 1 & 4.8 & 0 & 4.7 & 4.6 & 0 & 7.1 \\
\hline & $2-5$ & 43.4 & 10.6 & 38.0 & 45.1 & 8.1 & 34.8 \\
\hline & $6-10$ & 26.7 & 24.6 & 21.2 & 26.3 & 23.0 & 18.0 \\
\hline & $11-20$ & 16.4 & 30.4 & 19.3 & 15.7 & 33.3 & 25.5 \\
\hline & $21-30$ & 4.5 & 16.2 & 5.9 & 4.8 & 18.6 & 10.1 \\
\hline & $31+$ & 4.2 & 18.3 & 10.8 & 3.4 & 17.0 & 4.6 \\
\hline & Mean, median & $9.02,6$ & $18.84,15$ & $11.56,7$ & $8.54,6$ & $19.04,15$ & $10.39,6$ \\
\hline
\end{tabular}

* Weighted percentages may not sum to 100 because of missing data or exclusion of certain categories; percentages weighted to account for age, sex, region (Canada only), and race/ethnicity (U.S. only); 3565, $5 \mathrm{II}$, and 84 represent I38,802,5I 9, 20,060,4I2, and 3,453, I64 adults, respectively, in the U.S.; 2434, 397, and 51 represent 16,555,719, 2,723,870, and 381,147 adults, respectively, in Canada. tMost recent visit among respondents reporting at least one visit to a physician in the past 12 months. $\mathrm{GP}=$ general practitioner or family doctor; $\mathrm{DC}=$ Doctor of Chiropractic; NA = not applicable. 
ferences indicate that the types and patterns of care may vary between these two populations. Persons seeking both medical and chiropractic care may use chiropractic for musculoskeletal or neuromusculoskeletal problems, whereas persons who seek chiropractic care alone may use it more for wellness or preventive care, or, given lack of health insurance and lack of a regular doctor, for primary care as well. These distinctions have important implications for chiropractic health-care delivery models, which may necessarily vary and evolve within and across populations according to provider access, inter-professional cooperation and referral relationships, quality of available medical care, health insurance and economic resources, and provider and patient attitudes and beliefs, among others [15,36-43].

These findings suggest that the relative integration of chiropractic with medical care, and chiropractic's role in primary health-care delivery (vs. back and neck pain care), in North America and around the globe, are likely dependent on social, cultural, and environmental factors, individual and community resources, and personal preferences and predilections. Recent research has uncovered vast deficiencies in the delivery of primary care in several countries, but most notably in the U.S. [16]. Failure to (1) provide patient-centered care, (2) emphasize preventive care, (3) be aware of patients' health concerns, and (4) effectively manage chronic conditions are a few of the shortcomings identified. These deficiencies may be reflected in patients' perceptions of health-care quality and satisfaction, driving primary-care medical patients toward chiropractic. Given chiropractic's emphasis on disease prevention, health maintenance, and the patientdoctor relationship $[5,38,40,44]$, chiropractic may have a role in improving the effectiveness of and access to primary care domestically and internationally [43], and perhaps help to reduce health inequalities within and between countries [45]. Challenges abound, however, in the U.S. and around the world $(40,44)$. For example, according to the World Federation of Chiropractic's October 2004 survey of almost 3700 respondents worldwide [44], perceptions of the general public and medical doctors toward chiropractic vis-a-vis primary health care vs. management of back and neck pain differ markedly from how the chiropractic profession believes the public and medical doctors should perceive chiropractic. Furthermore, surveys of chiropractors and chiropractic patients from several countries around the world show that the vast majority of patients seek care for relief from back and neck pain and other neuromusculoskeletal complaints [46-52]. Although some between-country differences in patients have been observed, the use of consistent measures and methods across studies would be necessary to better estimate and interpret observed differences in patient populations [49].
The only other study using a representative sample of the U.S. population to compare users of medical care and chiropractic care identified several factors associated with the type of back care among those who sought health care for their back problem [13]. Specifically, adults with disabling comorbidities and back-related restricted-activity days were relatively less likely to use chiropractic care than primary medical care. Those who were male, white, highschool educated, single, employed, living in the West, and reporting more than nine doctor visits during the previous 12 months, a back condition of more than five years' duration, and no back-related disability were relatively more likely to use chiropractic care compared with primary medical care. Chiropractic patients also had better self-perceived general health status, fewer bed and restricted-activity days, and fewer comorbid conditions, compared with patients of other providers $[13,14]$. Additional studies of health-care use for back pain in the U.S. have found that residents in the West [10], whites $[10,11,46]$, males [11], high-school graduates [11,52], chronic back-pain sufferers [53], and persons with goodto-excellent self-reported health [12], adequate health insurance [12], and with less severe pain [12] are more likely to visit a chiropractor.

One Canadian study, a population-based cross-sectional survey of the Saskatchewan population 20-69 years old, found that persons with back or neck pain were more likely to consult a chiropractor alone rather than a medical doctor if they were younger, male, living in urban areas, not in the lower socioeconomic categories, and without arthritis, and with fewer comorbidities, less severe pain, and better physical and social functioning and higher scores on other health-related quality of life measures [15]. These results are generally not inconsistent with our findings among Canadian respondents, and compatible with a generally healthier segment of the population with back or neck pain having self selected chiropractic care. However, a study comparing chiropractic back pain patients with medical patients based primarily in the U.S. found that chiropractic patients had much worse mental health scores [36]. This finding is compatible with our results showing a higher prevalence of depression among chiropractic care seekers in the U.S., and a higher prevalence of mental health visits among chiropractic care seekers in Canada. Given that persons with back pain often have comorbid depression, as a cause, consequence or associated condition occurring with back pain through shared neural, immune, psychological, or other pathways [54,55], a not unsurprising finding. Asthma has also been shown to be associated with back pain and depression, possibly explaining the somewhat higher prevalence of asthmatics among chiropractic patients [56]. 
Table 6: Crude and adjusted effect estimates of socioeconomic and demographic, quality of life, and health-related factors on seeking in the past 12 months (I) any DC vs. GP care only and (2) DC only vs. both GP and DC care: Results from logistic regression analyses among U.S. respondents from the Joint Canada/US Survey of Health, 2002-03

\begin{tabular}{|c|c|c|c|c|c|c|c|c|c|c|c|}
\hline \multirow[b]{3}{*}{ Variable } & \multirow[b]{3}{*}{ Category } & \multicolumn{5}{|c|}{ Any DC vs. GP Care Only $(n=4160)$} & \multicolumn{5}{|c|}{ DC Only vs. GP+DC Care $(n=595)$} \\
\hline & & \multicolumn{5}{|c|}{ Adjusted effect estimates } & \multicolumn{5}{|c|}{ Adjusted effect estimates } \\
\hline & & $\begin{array}{l}\text { Crude } \\
\text { OR }\end{array}$ & $\begin{array}{l}\text { Model } \\
\text { I* OR }\end{array}$ & $95 \% \mathrm{Cl}$ & $\begin{array}{l}\text { Model } \\
2 \text { † OR }\end{array}$ & $95 \% \mathrm{Cl}$ & $\begin{array}{l}\text { Crude } \\
\text { OR }\end{array}$ & $\begin{array}{l}\text { Model } \\
\text { I*OR }\end{array}$ & $95 \% \mathrm{Cl}$ & $\begin{array}{l}\text { Model } \\
2 \dagger \text { OR }\end{array}$ & $95 \% \mathrm{Cl}$ \\
\hline \multirow[t]{4}{*}{ Age (Years) } & $18-44$ & 1.00 & 1.00 & & 1.00 & & 1.00 & 1.00 & & 1.00 & \\
\hline & $45-64$ & 1.07 & 1.00 & $(0.81,1.24)$ & 1.04 & $(0.83,1.32)$ & 0.53 & 0.57 & $(0.32,1.04)$ & 0.66 & $(0.36,1.21)$ \\
\hline & $\geq 65$ & 0.62 & 0.57 & $(0.44,0.76)$ & 0.73 & $(0.50,1.07)$ & 0.32 & 0.35 & $(0.16,0.81)$ & 0.61 & $(0.20,1.84)$ \\
\hline & Per 10 years & 0.90 & 0.90 & $(0.90,1.00)$ & 1.00 & $(0.90,1.11)$ & 0.73 & 0.82 & $(0.67,0.90)$ & 0.90 & $(0.74,1.11)$ \\
\hline \multirow[t]{2}{*}{ Sex } & Female & 1.00 & 1.00 & & 1.00 & & 1.00 & 1.00 & & & \\
\hline & Male & 0.93 & 0.91 & $(0.74,1.11)$ & 0.93 & $(0.76,1.15)$ & 1.40 & 1.36 & $(0.80,2.32)$ & 1.34 & $(0.78,2.32)$ \\
\hline \multirow[t]{2}{*}{ Race/ethnicity } & White only & 1.00 & 1.00 & & 1.00 & & 1.00 & 1.00 & & 1.00 & \\
\hline & $\begin{array}{l}\text { Other/ } \\
\text { multiple }\end{array}$ & 0.54 & 0.51 & $(0.39,0.68)$ & 0.50 & $(0.37,0.67)$ & 1.74 & 1.57 & $(0.78,3.16)$ & 0.97 & $(0.48,1.98)$ \\
\hline \multirow[t]{4}{*}{ Education } & $\begin{array}{l}\text { No H.S. } \\
\text { degree }\end{array}$ & 1.00 & 1.00 & & 1.00 & & 1.00 & 1.00 & & 1.00 & \\
\hline & H.S. degree & 1.30 & 1.01 & $(0.68,1.50)$ & 1.05 & $(0.68,1.62)$ & 0.87 & 0.84 & $(0.31,2.27)$ & 1.26 & $(0.38,4.17)$ \\
\hline & Some college & 1.31 & 1.01 & $(0.65,1.57)$ & 1.13 & $(0.70,1.80)$ & 1.18 & 1.12 & $(0.39,3.23)$ & 1.83 & $(0.50,6.68)$ \\
\hline & 4-year degree & 1.41 & 1.02 & $(0.68, \mid \mathrm{I} .5 \mathrm{I})$ & 1.11 & $(0.72, \mid .7 I)$ & 0.51 & 0.49 & $(0.18,1.34)$ & 0.87 & $(0.25,3.02)$ \\
\hline \multirow[t]{3}{*}{ Marital status } & Married & 1.00 & 1.00 & & 1.00 & & 1.00 & 1.00 & & 1.00 & \\
\hline & Was married & 0.86 & 0.97 & $(0.75,1.25)$ & 0.97 & $(0.74,1.28)$ & 0.96 & 1.12 & $(0.57,2.20)$ & 0.96 & $(0.48,1.92)$ \\
\hline & Single & 0.85 & 0.81 & $(0.61,1.09)$ & 0.85 & $(0.63,1.15)$ & 1.30 & 1.06 & $(0.52,2.17)$ & 1.05 & $(0.48,2.30)$ \\
\hline \multirow{5}{*}{$\begin{array}{l}\text { Income (adjusted } \\
\text { for household } \\
\text { size) }\end{array}$} & Highest quint. & 1.00 & 1.00 & & 1.00 & & 1.00 & 1.00 & & 1.00 & \\
\hline & Upper middle & 1.01 & 1.02 & $(0.73,1.43)$ & 1.00 & $(0.7 \mathrm{I}, \mathrm{I} .40)$ & 0.94 & 0.97 & $(0.38,2.5 \mathrm{I})$ & 0.93 & $(0.36,2.40)$ \\
\hline & Middle & 0.84 & 0.91 & $(0.64,1.29)$ & 0.89 & $(0.62,1.27)$ & 0.96 & 0.96 & $(0.39,2.37)$ & 0.82 & $(0.31,2.14)$ \\
\hline & Lower middle & 0.90 & 1.04 & $(0.73,1.48)$ & 1.00 & $(0.69,1.46)$ & 0.95 & 1.02 & $(0.39,2.65)$ & 0.51 & $(0.17,1.55)$ \\
\hline & Lowest quint. & 0.62 & 0.79 & $(0.54,1.17)$ & 0.72 & $(0.46,1.15)$ & 1.63 & 1.88 & $(0.73,4.83)$ & 1.43 & $(0.49,4.19)$ \\
\hline \multirow{2}{*}{$\begin{array}{l}\text { Main income } \\
\text { source }\end{array}$} & Employment & 1.00 & 1.00 & & 1.00 & & 1.00 & 1.00 & & 1.00 & \\
\hline & Other & 0.66 & 0.79 & $(0.58,1.07)$ & 0.78 & $(0.57,1.06)$ & 0.52 & 0.69 & $(0.30,1.55)$ & 0.73 & $(0.26,2.04)$ \\
\hline $\mathrm{HUI}$ & Per 0.1 unit & 1.02 & 1.00 & $(0.95,1.05)$ & 1.00 & $(0.95,1.05)$ & 1.01 & 0.99 & $(0.89,1.12)$ & 1.00 & $(0.87,1.14)$ \\
\hline \multirow[t]{4}{*}{ Self-rated health } & Excellent & 1.00 & 1.00 & & 1.00 & & 1.00 & 1.00 & & 1.00 & \\
\hline & Very good & 1.01 & 1.06 & $(0.8 \mathrm{I}, 1.37)$ & 1.04 & $(0.80,1.35)$ & 0.59 & 0.63 & $(0.31,1.26)$ & 0.72 & $(0.35,1.49)$ \\
\hline & Good & 0.82 & 0.90 & $(0.67,1.19)$ & 0.92 & $(0.68,1.24)$ & 1.20 & 1.30 & $(0.66,2.54)$ & 1.01 & $(0.48,2.13)$ \\
\hline & Fair or poor & 0.65 & 0.79 & $(0.56,1.13)$ & 0.70 & $(0.45,1.10)$ & 0.49 & 0.62 & $(0.20,1.88)$ & 0.69 & $(0.20,2.30)$ \\
\hline $\begin{array}{l}\text { Depression (past } \\
\text { year) }\end{array}$ & I+ episodes & 1.34 & 1.30 & $(0.95,1.79)$ & 1.31 & $(0.91,1.90)$ & 1.02 & 0.99 & $(0.43,2.27)$ & 1.08 & $(0.42,2.75)$ \\
\hline $\begin{array}{l}\text { Mental health } \\
\text { (past year) }\end{array}$ & I+ visits & 1.29 & 1.19 & $(0.91,1.56)$ & 1.15 & $(0.84,1.56)$ & 0.42 & 0.45 & $(0.16,1.23)$ & 0.26 & $(0.08,0.82)$ \\
\hline Emotional & Happy in life & 1.00 & 1.00 & & 1.00 & & 1.00 & 1.00 & & 1.00 & \\
\hline problems & Not happy & 1.03 & 1.02 & $(0.80,1.30)$ & 0.93 & $(0.69,1.26)$ & 0.99 & 1.02 & $(0.53,1.98)$ & 0.60 & $(0.26,1.39)$ \\
\hline \multirow{10}{*}{$\begin{array}{l}\text { Chronic } \\
\text { conditions } \\
\text { (lifetime history) }\end{array}$} & Asthma & 1.11 & 1.12 & $(0.83,1.50)$ & 1.12 & $(0.83,1.53)$ & 0.20 & 0.21 & $(0.07,0.58)$ & 0.21 & $(0.07,0.62)$ \\
\hline & Arthritis & 1.12 & 1.32 & $(1.02,1.69)$ & 1.38 & $(1.05,1.81)$ & 0.68 & 0.95 & $(0.47,1.92)$ & 1.12 & $(0.52,2.43)$ \\
\hline & Hypertension & 0.66 & 0.73 & $(0.56,0.94)$ & 0.74 & $(0.56,0.98)$ & 0.12 & 0.13 & $(0.04,0.46)$ & 0.15 & $(0.04,0.55)$ \\
\hline & Emphysema & 0.72 & 0.78 & $(0.41,1.49)$ & 0.80 & $(0.38,1.69)$ & 0.43 & 0.45 & $(0.05,3.79)$ & 0.59 & $(0.06,6.13)$ \\
\hline & Diabetes & 0.57 & 0.71 & $(0.46,1.08)$ & 0.71 & $(0.45,1.11)$ & $\ddagger$ & $\ddagger$ & & $\ddagger$ & \\
\hline & Heart disease & 0.60 & 0.77 & $(0.48,1.23)$ & 0.83 & $(0.50,1.37)$ & 0.59 & 0.83 & $(0.26,2.63)$ & 1.14 & $(0.37,3.49)$ \\
\hline & $\mathrm{CHD}$ & 0.66 & 0.90 & $(0.44,1.85)$ & 0.92 & $(0.42,1.99)$ & 0.25 & 0.30 & $(0.03,2.95)$ & 0.49 & $(0.06,4.25)$ \\
\hline & Angina & 0.42 & 0.54 & $(0.28,1.03)$ & 0.57 & $(0.28,1.14)$ & 1.80 & 2.98 & $\begin{array}{l}(0.71 \\
12.47)\end{array}$ & 4.09 & $\begin{array}{l}(0.92 \\
18.10)\end{array}$ \\
\hline & I or more & 0.83 & 0.93 & $(0.74,1.17)$ & 0.94 & $(0.74,1.19)$ & 0.33 & 0.38 & $(0.20,0.74)$ & 0.40 & $(0.19,0.82)$ \\
\hline & Per condition & 0.88 & 0.94 & $(0.86,1.03)$ & 0.94 & $(0.85,1.05)$ & 0.50 & 0.53 & $(0.36,0.78)$ & 0.56 & $(0.38,0.83)$ \\
\hline \multirow[t]{2}{*}{ Pain/activity limits } & No pain & 1.00 & 1.00 & & 1.00 & & 1.00 & 1.00 & & 1.00 & \\
\hline & Pain & 1.26 & 1.37 & $(1.08,1.72)$ & 1.70 & $(1.24,2.33)$ & 0.79 & 0.94 & $(0.50,1.78)$ & 1.12 & $(0.53,2.39)$ \\
\hline \multirow{2}{*}{$\begin{array}{l}\text { Activity } \\
\text { restrictions }\end{array}$} & Never & & 1.00 & 1.00 & & 1.00 & & 1.00 & 1.00 & & 1.00 \\
\hline & Sometimes & 1.29 & 1.34 & $(1.05,1.69)$ & 1.39 & $(1.07,1.81)$ & 0.87 & 1.02 & $(0.53,1.95)$ & 0.94 & $(0.47,1.87)$ \\
\hline
\end{tabular}


Table 6: Crude and adjusted effect estimates of socioeconomic and demographic, quality of life, and health-related factors on seeking in the past 12 months (I) any DC vs. GP care only and (2) DC only vs. both GP and DC care: Results from logistic regression analyses among U.S. respondents from the Joint Canada/US Survey of Health, 2002-03 (Continued)

\begin{tabular}{|c|c|c|c|c|c|c|c|c|c|c|c|}
\hline & Often & 0.90 & 1.07 & $(0.77,1.49)$ & 1.19 & $(0.77,1.83)$ & 0.48 & 0.54 & $(0.19,1.58)$ & 0.50 & $(0.16,1.58)$ \\
\hline \multirow{2}{*}{$\begin{array}{l}\text { Back/neck } \\
\text { problems }\end{array}$} & None & 1.00 & 1.00 & & 1.00 & & 1.00 & 1.00 & & 1.00 & \\
\hline & Disabling & 1.99 & 2.14 & $(1.62,2.83)$ & 2.19 & $(1.62,2.96)$ & 0.72 & 0.75 & $(0.34,1.69)$ & 1.04 & $(0.44,2.43)$ \\
\hline \multirow[t]{3}{*}{ Smoking status } & Never & 1.00 & 1.00 & & 1.00 & & 1.00 & 1.00 & & 1.00 & \\
\hline & Past & 1.21 & 1.26 & $(1.00,1.60)$ & 1.25 & $(0.98,1.60)$ & 0.95 & 1.10 & $(0.59,2.04)$ & 1.32 & $(0.68,2.58)$ \\
\hline & Current & 0.99 & 0.98 & $(0.75,1.28)$ & 0.97 & $(0.73,1.30)$ & 0.71 & 0.64 & $(0.31,1.35)$ & 0.68 & $(0.32,1.47)$ \\
\hline \multirow[t]{3}{*}{ Body weight } & Under/normal & 1.00 & 1.00 & & 1.00 & & 1.00 & 1.00 & & 1.00 & \\
\hline & Overweight & 1.07 & 1.15 & $(0.91,1.46)$ & 1.16 & $(0.91,1.47)$ & 1.44 & 1.52 & $(0.79,2.94)$ & 1.64 & $(0.82,3.24)$ \\
\hline & Obese & 1.16 & 1.30 & $(1.00,1.69)$ & 1.29 & $(0.98,1.69)$ & 0.84 & 0.85 & $(0.41,1.77)$ & 0.78 & $(0.35,1.73)$ \\
\hline \multirow{3}{*}{$\begin{array}{l}\text { Physical activity } \\
\text { (past } 3 \text { months) }\end{array}$} & Active & 1.00 & 1.00 & & 1.00 & & 1.00 & 1.00 & & 1.00 & \\
\hline & Moderate & 0.96 & 0.97 & $(0.72,1.32)$ & 1.03 & $(0.75, I .40)$ & 1.05 & 1.12 & $(0.48,2.62)$ & 1.02 & $(0.42,2.43)$ \\
\hline & Inactive & 0.91 & 0.94 & $(0.73,1.21)$ & 0.93 & $(0.71,1.21)$ & 1.37 & 1.49 & $(0.75,2.98)$ & 1.21 & $(0.60,2.46)$ \\
\hline \multirow{3}{*}{$\begin{array}{l}\text { Activity frequency } \\
\text { (past } 3 \text { months) }\end{array}$} & Regular & 1.00 & 1.00 & & 1.00 & & 1.00 & 1.00 & & 1.00 & \\
\hline & Occasional & 1.12 & 1.13 & $(0.87,1.48)$ & 1.15 & $(0.87,1.52)$ & 0.68 & 0.67 & $(0.30,1.46)$ & 0.60 & $(0.26,1.39)$ \\
\hline & Infrequent & 0.93 & 1.00 & $(0.79,1.27)$ & 0.97 & $(0.74,1.26)$ & 1.21 & 1.27 & $(0.68,2.35)$ & 1.11 & $(0.57,2.17)$ \\
\hline \multirow{2}{*}{$\begin{array}{l}\text { Hospitalization } \\
\text { (past year) }\end{array}$} & None & 1.00 & 1.00 & & 1.00 & & 1.00 & 1.00 & & 1.00 & \\
\hline & I or more & 0.87 & 0.86 & $(0.63,1.19)$ & 0.85 & $(0.60,1.21)$ & 0.38 & 0.45 & $(0.16,1.23)$ & 0.58 & $(0.19,1.70)$ \\
\hline \multirow{2}{*}{$\begin{array}{l}\text { Prescriptions } \\
\text { (past month) }\end{array}$} & None & 1.00 & 1.00 & & 1.00 & & 1.00 & 1.00 & & 1.00 & \\
\hline & I or more & 0.97 & 0.99 & $(0.79,1.25)$ & 1.04 & $(0.82, I .3 \mathrm{I})$ & 0.20 & 0.23 & $(0.13,0.42)$ & 0.23 & $(0.12,0.44)$ \\
\hline $\begin{array}{l}\text { Medications (past } \\
2 \text { days) }\end{array}$ & $\begin{array}{l}\text { Per } \\
\text { medication }\end{array}$ & 0.94 & 0.95 & $(0.89,1.02)$ & 0.96 & $(0.89,1.03)$ & 0.50 & 0.53 & $(0.38,0.72)$ & 0.51 & $(0.36,0.70)$ \\
\hline $\begin{array}{l}\text { Insurance (past } \\
\text { year) }\end{array}$ & Insured & 0.81 & 0.74 & $(0.5 \mathrm{I}, \mathrm{I} .07)$ & 0.73 & $(0.49,1.07)$ & 0.17 & 0.18 & $(0.09,0.38)$ & 0.21 & $(0.10,0.44)$ \\
\hline \multirow{2}{*}{$\begin{array}{l}\text { Unmet needs } \\
\text { (past year) }\end{array}$} & None & 1.00 & 1.00 & & 1.00 & & 1.00 & 1.00 & & 1.00 & \\
\hline & Any & 1.03 & 1.04 & $(0.77,1.40)$ & 0.99 & $(0.70,1.39)$ & 0.85 & 0.79 & $(0.36,1.73)$ & 0.61 & $(0.21,1.74)$ \\
\hline \multirow{2}{*}{$\begin{array}{l}\text { Regular doctor } \\
\text { (past year) }\end{array}$} & No & 1.00 & 1.00 & & 1.00 & & 1.00 & 1.00 & & 1.00 & \\
\hline & Yes & 0.60 & 0.61 & $(0.45,0.8 \mathrm{I})$ & 0.59 & $(0.44,0.81)$ & 0.09 & 0.10 & $(0.05,0.17)$ & 0.09 & $(0.05,0.18)$ \\
\hline \multirow{3}{*}{$\begin{array}{l}\text { Health care } \\
\text { quality (past year) }\end{array}$} & Excellent & 1.00 & 1.00 & & 1.00 & & 1.00 & 1.00 & & 1.00 & \\
\hline & Good & 0.94 & 0.97 & $(0.79,1.20)$ & 0.93 & $(0.74,1.16)$ & 1.40 & 1.40 & $(0.79,2.46)$ & 1.30 & $(0.71,2.38)$ \\
\hline & Fair or poor & 0.95 & 1.00 & $(0.72,1.39)$ & 0.95 & $(0.67,1.35)$ & 1.17 & 1.11 & $(0.47,2.62)$ & 1.09 & $(0.39,3.04)$ \\
\hline \multirow{3}{*}{$\begin{array}{l}\text { Health care } \\
\text { satisfaction (past } \\
\text { year) }\end{array}$} & Very satisfied & 1.00 & 1.00 & & 1.00 & & 1.00 & 1.00 & & 1.00 & \\
\hline & Somewhat sat. & 1.04 & 1.03 & $(0.83,1.29)$ & 0.96 & $(0.77,1.21)$ & 1.73 & 1.57 & $(0.88,2.80)$ & 1.31 & $(0.70,2.48)$ \\
\hline & Not satisfied & 1.09 & 1.12 & $(0.8 \mathrm{I}, 1.56)$ & 1.03 & $(0.73,1.47)$ & 3.35 & 2.57 & $(1.26,5.23)$ & 2.83 & $(1.26,6.36)$ \\
\hline \multirow{3}{*}{$\begin{array}{l}\text { Quality of MD } \\
\text { care (past year) }\end{array}$} & Excellent & 1.00 & 1.00 & & 1.00 & & 1.00 & 1.00 & & 1.00 & \\
\hline & Good & 0.95 & 0.97 & $(0.76,1.24)$ & 0.94 & $(0.73,1.21)$ & 0.46 & 0.51 & $(0.20,1.27)$ & 0.56 & $(0.20,1.55)$ \\
\hline & Fair or poor & 0.69 & 0.75 & $(0.47,1.21)$ & 0.71 & $(0.43,1.19)$ & 1.29 & 1.32 & $(0.33,5.27)$ & 1.58 & $(0.32,7.97)$ \\
\hline \multirow{3}{*}{$\begin{array}{l}\text { Satisfaction of MD } \\
\text { care (past year) }\end{array}$} & Very satisfied & 1.00 & 1.00 & & 1.00 & & 1.00 & 1.00 & & 1.00 & \\
\hline & Somewhat sat. & 0.84 & 0.83 & $(0.63,1.09)$ & 0.77 & $(0.58,1.03)$ & 1.89 & 1.70 & $(0.68,4.30)$ & 1.73 & $(0.64,4.68)$ \\
\hline & Not satisfied & 0.83 & 0.81 & $(0.48,1.37)$ & 0.72 & $(0.41,1.29)$ & 1.26 & 1.09 & $(0.23,5.22)$ & 0.99 & $(0.15,6.27)$ \\
\hline
\end{tabular}

* Estimated effects adjusted for age ( $18-44,45-64,65+$ years), sex, and race/ethnicity (white only, other/multiple races or ethnicities). † Estimated effects adjusted for age (18-44, 45-64, 65+ years), sex, race/ethnicity (white only, other/multiple races or ethnicities), education (no high school degree, high school degree or GED, some college, 4-year college degree or certificate), main source of income (employment, other sources), health-related quality of life (Health Utility Index score [continuous]), and health insurance status (insured in past 12 months, not insured in past 12 months).

$¥$ Odds ratio not shown because of singularities in data for fitting model.

$\mathrm{OR}=$ odds ratio; $\mathrm{Cl}=$ confidence interval; $\mathrm{GP}=$ general practitioner or family doctor; $\mathrm{DC}=$ Doctor of Chiropractic; HUI = Health Utility Index; $\mathrm{CHD}=$ coronary heart disease; $\mathrm{MD}=$ medical doctor. 
Table 7: Crude and adjusted effect estimates of socioeconomic and demographic, quality of life, and health-related factors on seeking in the past 12 months (I) any DC vs. GP care only and (2) DC only vs. both GP and DC care: Results from logistic regression analyses among Canadian respondents from the Joint Canada/US Survey of Health, 2002-03

\begin{tabular}{|c|c|c|c|c|c|c|c|c|c|c|c|}
\hline \multirow[b]{3}{*}{ Variable } & \multirow[b]{3}{*}{ Category } & \multicolumn{5}{|c|}{ Any DC vs. GP Care Only $(n=2882)$} & \multicolumn{5}{|c|}{ DC Only vs. GP+DC Care $(n=448)$} \\
\hline & & \multicolumn{5}{|c|}{ Adjusted effect estimates } & \multicolumn{5}{|c|}{ Adjusted effect estimates } \\
\hline & & $\begin{array}{l}\text { Crude } \\
\text { OR }\end{array}$ & $\begin{array}{l}\text { Model } \\
\text { I* OR }\end{array}$ & $95 \% \mathrm{Cl}$ & $\begin{array}{l}\text { Model } \\
2 \dagger O R\end{array}$ & $95 \% \mathrm{Cl}$ & $\begin{array}{l}\text { Crude } \\
\text { OR }\end{array}$ & $\begin{array}{l}\text { Model } \\
\text { I* OR }\end{array}$ & $95 \% \mathrm{Cl}$ & $\begin{array}{l}\text { Model } \\
2 † O R\end{array}$ & $95 \% \mathrm{Cl}$ \\
\hline \multirow[t]{4}{*}{ Age (Years) } & $18-44$ & 1.00 & 1.00 & & 1.00 & & 1.00 & 1.00 & & 1.00 & \\
\hline & $45-64$ & 0.86 & 0.83 & $(0.64,1.07)$ & 0.85 & $(0.66,1.11)$ & 0.29 & 0.29 & $(0.11,0.73)$ & 0.34 & $(0.12,0.94)$ \\
\hline & $\geq 65$ & 0.49 & 0.49 & $(0.36,0.67)$ & 0.68 & $(0.44,1.04)$ & 0.18 & 0.17 & $(0.05,0.61)$ & 0.18 & $(0.05,0.7 I)$ \\
\hline & Per 10 years & 0.90 & 0.90 & $(0.82,0.90)$ & 1.00 & $(0.90,1.00)$ & 0.60 & 0.61 & $(0.45,0.74)$ & 0.61 & $(0.45,0.82)$ \\
\hline \multirow[t]{2}{*}{ Sex } & Female & 1.00 & 1.00 & & 1.00 & & 1.00 & 1.00 & & 1.00 & \\
\hline & Male & 1.06 & 1.05 & $(0.83, \mid .3 \mathrm{I})$ & 1.03 & $(0.82,1.30)$ & 4.55 & 4.65 & $(2.19,9.87)$ & 3.63 & $(1.67,7.90)$ \\
\hline \multirow[t]{2}{*}{ Race/ethnicity } & White only & 1.00 & 1.00 & & 1.00 & & 1.00 & 1.00 & & 1.00 & \\
\hline & $\begin{array}{l}\text { Other/ } \\
\text { multiple }\end{array}$ & 0.65 & 0.62 & $(0.44,0.87)$ & 0.61 & $(0.42,0.87)$ & 1.15 & 1.12 & $(0.46,2.76)$ & 1.29 & $(0.53,3.16)$ \\
\hline \multirow[t]{4}{*}{ Education } & $\begin{array}{l}\text { No H.S. } \\
\text { degree }\end{array}$ & 1.00 & 1.00 & & 1.00 & & 1.00 & 1.00 & & 1.00 & \\
\hline & H.S. degree & 1.52 & 1.32 & $(0.92,1.90)$ & 1.42 & $(0.98,2.06)$ & 0.73 & 0.48 & $(0.17,1.40)$ & 0.61 & $(0.20,1.85)$ \\
\hline & Some college & 1.28 & 1.09 & $(0.73,1.60)$ & 1.19 & $(0.80,1.77)$ & 0.66 & 0.61 & $(0.22,1.65)$ & 0.78 & $(0.26,2.36)$ \\
\hline & 4-year degree & 1.58 & 1.40 & $(0.97,2.02)$ & 1.52 & $(1.05,2.20)$ & 0.29 & 0.23 & $(0.08,0.70)$ & 0.30 & $(0.09,1.00)$ \\
\hline \multirow[t]{3}{*}{ Marital status } & Married & 1.00 & 1.00 & & 1.00 & & 1.00 & 1.00 & & 1.00 & \\
\hline & Was married & 0.77 & 0.92 & $(0.68,1.25)$ & 0.93 & $(0.67,1.29)$ & 0.25 & 0.49 & $(0.13,1.86)$ & 0.51 & $(0.14,1.84)$ \\
\hline & Single & 0.87 & 0.77 & $(0.56,1.07)$ & 0.73 & $(0.52,1.01)$ & 2.70 & 1.84 & $(0.82,4.10)$ & 1.55 & $(0.65,3.70)$ \\
\hline \multirow{5}{*}{$\begin{array}{l}\text { Income (adjusted } \\
\text { for household } \\
\text { size) }\end{array}$} & Highest quint. & 1.00 & 1.00 & & 1.00 & & 1.00 & 1.00 & & 1.00 & \\
\hline & Upper middle & 0.84 & 0.81 & $(0.56,1.16)$ & 0.80 & $(0.55,1.16)$ & 1.43 & 1.63 & $(0.5 \mathrm{I}, 5.23)$ & 1.56 & $(0.50,4.90)$ \\
\hline & Middle & 0.71 & 0.70 & $(0.48,1.04)$ & 0.71 & $(0.47,1.07)$ & 2.11 & 2.23 & $(0.64,7.79)$ & 1.93 & $(0.51,7.25)$ \\
\hline & Lower middle & 0.79 & 0.83 & $(0.57,1.22)$ & 0.84 & $(0.56,1.27)$ & 2.33 & 2.82 & $(0.88,8.97)$ & 2.45 & $(0.70,8.59)$ \\
\hline & Lowest quint. & 0.44 & 0.49 & $(0.32,0.73)$ & 0.49 & $(0.30,0.80)$ & 1.76 & 2.34 & $(0.64,8.55)$ & 2.15 & $(0.46,9.96)$ \\
\hline \multirow{2}{*}{$\begin{array}{l}\text { Main income } \\
\text { source }\end{array}$} & Employment & 1.00 & 1.00 & & 1.00 & & 1.00 & 1.00 & & 1.00 & \\
\hline & Other & 0.62 & 0.78 & $(0.55,1.12)$ & 0.76 & $(0.53,1.11)$ & 0.38 & 0.86 & $(0.30,2.45)$ & 0.92 & $(0.33,2.52)$ \\
\hline $\mathrm{HUI}$ & Per 0.1 unit & 0.99 & 0.97 & $(0.93,1.02)$ & 0.95 & $(0.90,1.00)$ & 1.25 & 1.12 & $(0.90,1.40)$ & 1.12 & $(0.89,1.41)$ \\
\hline \multirow[t]{4}{*}{ Self-rated health } & Excellent & 1.00 & 1.00 & & 1.00 & & 1.00 & 1.00 & & 1.00 & \\
\hline & Very good & 0.93 & 0.96 & $(0.7 \mathrm{I}, \mathrm{I} .30)$ & 1.01 & $(0.74,1.37)$ & 0.51 & 0.58 & $(0.26,1.29)$ & 0.58 & $(0.26,1.30)$ \\
\hline & Good & 0.76 & 0.88 & $(0.63,1.23)$ & 0.95 & $(0.67,1.34)$ & 0.55 & 0.76 & $(0.29,1.98)$ & 0.70 & $(0.24,2.03)$ \\
\hline & Fair or poor & 0.83 & 1.03 & $(0.68,1.56)$ & 1.11 & $(0.65,1.87)$ & 0.08 & 0.11 & $(0.01,0.86)$ & 0.09 & $(0.01,0.66)$ \\
\hline $\begin{array}{l}\text { Depression (past } \\
\text { year) }\end{array}$ & I+ episodes & 1.06 & 0.96 & $(0.64,1.44)$ & 0.95 & $(0.6 \mathrm{I}, 1.47)$ & 0.33 & 0.38 & $(0.08,1.73)$ & 0.39 & $(0.08,2.04)$ \\
\hline $\begin{array}{l}\text { Mental health } \\
\text { (past year) }\end{array}$ & I+ visits & 1.34 & 1.25 & $(0.90,1.74)$ & 1.23 & $(0.87,1.74)$ & $\ddagger$ & $\ddagger$ & & $\ddagger$ & \\
\hline \multirow{2}{*}{$\begin{array}{l}\text { Emotional } \\
\text { problems }\end{array}$} & Happy in life & 1.00 & 1.00 & & 1.00 & & 1.00 & 1.00 & & 1.00 & \\
\hline & Not happy & 0.75 & 0.76 & $(0.56,1.03)$ & 0.70 & $(0.50,0.99)$ & 1.10 & 1.64 & $(0.6 \mathrm{I}, 4.40)$ & 2.80 & $(0.93,8.44)$ \\
\hline \multirow{10}{*}{$\begin{array}{l}\text { Chronic } \\
\text { conditions } \\
\text { (lifetime history) }\end{array}$} & Asthma & 1.15 & 1.07 & $(0.76,1.52)$ & 1.12 & $(0.78,1.61)$ & 0.81 & 0.67 & $(0.21,2.12)$ & 0.81 & $(0.25,2.68)$ \\
\hline & Arthritis & 1.08 & 1.37 & $(1.02,1.83)$ & 1.33 & $(0.98,1.82)$ & $\ddagger$ & $\ddagger$ & & $\ddagger$ & \\
\hline & Hypertension & 0.53 & 0.62 & $(0.45,0.86)$ & 0.65 & $(0.46,0.91)$ & 0.15 & 0.26 & $(0.05,1.35)$ & 0.30 & $(0.06,1.58)$ \\
\hline & Emphysema & 0.84 & 0.99 & $(0.39,2.52)$ & 1.02 & $(0.39,2.72)$ & $\ddagger$ & $\ddagger$ & & $\ddagger$ & \\
\hline & Diabetes & 0.65 & 0.79 & $(0.44,1.42)$ & 0.77 & $(0.42,1.42)$ & 0.15 & 0.25 & $(0.03,2.43)$ & 0.25 & $(0.02,2.97)$ \\
\hline & Heart disease & 0.72 & 0.90 & $(0.53,1.50)$ & 0.96 & $(0.57,1.61)$ & 0.18 & 0.33 & $(0.04,2.60)$ & 0.46 & $(0.05,3.88)$ \\
\hline & $\mathrm{CHD}$ & 0.58 & 0.72 & $(0.28,1.80)$ & 0.74 & $(0.29,1.88)$ & 0.66 & 1.60 & $(0.25,10.30)$ & 1.89 & $\begin{array}{l}(0.18 \\
20.44)\end{array}$ \\
\hline & Angina & 0.42 & 0.57 & $(0.28,1.15)$ & 0.61 & $(0.29,1.27)$ & $\ddagger$ & $\ddagger$ & & $\ddagger$ & \\
\hline & I or more & 0.84 & 1.03 & $(0.80,1.33)$ & 1.05 & $(0.80,1.37)$ & 0.14 & 0.19 & $(0.07,0.56)$ & 0.20 & $(0.06,0.67)$ \\
\hline & Per condition & 0.88 & 0.96 & $(0.85,1.08)$ & 0.97 & $(0.85,1.10)$ & 0.29 & 0.34 & $(0.15,0.78)$ & 0.36 & $(0.14,0.91)$ \\
\hline \multirow[t]{2}{*}{ Pain/activity limits } & No pain & 1.00 & 1.00 & & 1.00 & & 1.00 & 1.00 & & 1.00 & \\
\hline & Pain & 1.46 & 1.58 & $(1.20,2.07)$ & 1.92 & $(1.34,2.76)$ & 0.30 & 0.38 & $(0.14,1.00)$ & 0.30 & $(0.07,1.18)$ \\
\hline Activity & Never & & 1.00 & 1.00 & & 1.00 & & 1.00 & 1.00 & & 1.00 \\
\hline
\end{tabular}


Table 7: Crude and adjusted effect estimates of socioeconomic and demographic, quality of life, and health-related factors on seeking in the past 12 months (I) any DC vs. GP care only and (2) DC only vs. both GP and DC care: Results from logistic regression analyses among Canadian respondents from the Joint Canada/US Survey of Health, 2002-03 (Continued)

\begin{tabular}{|c|c|c|c|c|c|c|c|c|c|c|c|}
\hline & Sometimes & 1.33 & 1.41 & $(1.09,1.84)$ & 1.43 & $(1.08,1.89)$ & 0.35 & 0.38 & $(0.16,0.92)$ & 0.39 & $(0.16,0.96)$ \\
\hline & Often & 0.96 & 1.05 & $(0.73,1.5 \mathrm{I})$ & 1.06 & $(0.66,1.72)$ & 0.50 & 0.61 & $(0.19,1.95)$ & 0.56 & $(0.13,2.54)$ \\
\hline \multirow{2}{*}{$\begin{array}{l}\text { Back/neck } \\
\text { problems }\end{array}$} & None & 1.00 & 1.00 & & 1.00 & & 1.00 & 1.00 & & 1.00 & \\
\hline & Disabling & 2.27 & 2.37 & $(1.76,3.19)$ & 2.38 & $(1.73,3.29)$ & 0.20 & 0.18 & $(0.06,0.58)$ & 0.19 & $(0.07,0.56)$ \\
\hline \multirow[t]{3}{*}{ Smoking status } & Never & 1.00 & 1.00 & & 1.00 & & 1.00 & 1.00 & & 1.00 & \\
\hline & Past & 1.12 & 1.15 & $(0.88,1.50)$ & 1.20 & $(0.91,1.57)$ & 0.23 & 0.24 & $(0.08,0.72)$ & 0.22 & $(0.07,0.64)$ \\
\hline & Current & 1.02 & 0.94 & $(0.69,1.27)$ & 0.96 & $(0.70,1.32)$ & 2.61 & 2.77 & $(1.29,5.95)$ & 2.13 & $(0.97,4.65)$ \\
\hline \multirow[t]{3}{*}{ Body weight } & Under/normal & 1.00 & 1.00 & & 1.00 & & 1.00 & 1.00 & & 1.00 & \\
\hline & Overweight & 1.12 & 1.14 & $(0.88,1.48)$ & 1.11 & $(0.85,1.44)$ & 0.81 & 0.60 & $(0.27,1.34)$ & 0.55 & $(0.25,1.22)$ \\
\hline & Obese & 0.99 & 0.97 & $(0.69,1.36)$ & 0.97 & $(0.69,1.37)$ & 0.46 & 0.24 & $(0.07,0.83)$ & 0.24 & $(0.07,0.83)$ \\
\hline \multirow{3}{*}{$\begin{array}{l}\text { Physical activity } \\
\text { (past } 3 \text { months) }\end{array}$} & Active & 1.00 & 1.00 & & 1.00 & & 1.00 & 1.00 & & 1.00 & \\
\hline & Moderate & 0.91 & 0.95 & $(0.70,1.29)$ & 0.96 & $(0.70,1.3 \mathrm{I})$ & 1.09 & 1.71 & $(0.67,4.38)$ & 1.56 & $(0.61,4.02)$ \\
\hline & Inactive & 0.95 & 1.02 & $(0.77,1.35)$ & 0.99 & $(0.74,1.32)$ & 1.60 & 2.25 & $(0.93,5.45)$ & 1.75 & $(0.71,4.33)$ \\
\hline \multirow{3}{*}{$\begin{array}{l}\text { Activity } \\
\text { frequency (past } 3 \\
\text { months) }\end{array}$} & Regular & 1.00 & 1.00 & & 1.00 & & 1.00 & 1.00 & & 1.00 & \\
\hline & Occasional & 1.15 & 1.16 & $(0.85,1.58)$ & 1.17 & $(0.86,1.60)$ & 1.09 & 0.85 & $(0.28,2.62)$ & 0.82 & $(0.27,2.50)$ \\
\hline & Infrequent & 0.81 & 0.91 & $(0.65,1.28)$ & 0.81 & $(0.56,1.17)$ & 2.29 & 3.74 & $(1.62,8.66)$ & 2.42 & $(0.89,6.60)$ \\
\hline \multirow{2}{*}{$\begin{array}{l}\text { Hospitalization } \\
\text { (past year) }\end{array}$} & None & 1.00 & 1.00 & & 1.00 & & 1.00 & 1.00 & & 1.00 & \\
\hline & I or more & 0.70 & 0.75 & $(0.5 \mathrm{I}, \mathrm{I} . \mathrm{II})$ & 0.74 & $(0.49,1.10)$ & 0.64 & 0.89 & $(0.22,3.53)$ & 1.11 & $(0.26,4.70)$ \\
\hline \multirow{2}{*}{$\begin{array}{l}\text { Prescriptions } \\
\text { (past month) }\end{array}$} & None & 1.00 & 1.00 & & 1.00 & & 1.00 & 1.00 & & 1.00 & \\
\hline & I or more & 0.76 & 0.85 & $(0.67,1.09)$ & 0.86 & $(0.67,1.10)$ & 0.13 & 0.19 & $(0.07,0.49)$ & 0.21 & $(0.08,0.57)$ \\
\hline $\begin{array}{l}\text { Medications (past } \\
2 \text { days) }\end{array}$ & $\begin{array}{l}\text { Per } \\
\text { medication }\end{array}$ & 0.92 & 0.96 & $(0.86,1.07)$ & 0.96 & $(0.85,1.08)$ & 0.19 & 0.25 & $(0.09,0.68)$ & 0.26 & $(0.10,0.65)$ \\
\hline \multirow{2}{*}{$\begin{array}{l}\text { Unmet needs } \\
\text { (past year) }\end{array}$} & None & 1.00 & 1.00 & & 1.00 & & 1.00 & 1.00 & & 1.00 & \\
\hline & Any & 1.06 & 1.01 & $(0.72, I .4 I)$ & 1.00 & $(0.70,1.43)$ & 0.86 & 0.78 & $(0.30,2.05)$ & 1.02 & $(0.34,3.08)$ \\
\hline \multirow{2}{*}{$\begin{array}{l}\text { Regular doctor } \\
\text { (past year) }\end{array}$} & No & 1.00 & 1.00 & & 1.00 & & 1.00 & 1.00 & & 1.00 & \\
\hline & Yes & 0.79 & 0.88 & $(0.60,1.29)$ & 0.95 & $(0.65,1.40)$ & 0.16 & 0.24 & $(0.10,0.56)$ & 0.25 & $(0.10,0.63)$ \\
\hline \multirow{3}{*}{$\begin{array}{l}\text { Health care } \\
\text { quality (past year) }\end{array}$} & Excellent & 1.00 & 1.00 & & 1.00 & & 1.00 & 1.00 & & 1.00 & \\
\hline & Good & 1.22 & 1.20 & $(0.93,1.55)$ & 1.24 & $(0.96,1.60)$ & 2.10 & 2.21 & $(0.93,5.25)$ & 2.08 & $(0.83,5.20)$ \\
\hline & Fair or poor & $\mathrm{I} .40$ & 1.39 & $(0.98,1.98)$ & 1.36 & $(0.94,1.95)$ & 2.49 & 2.01 & $(0.70,5.75)$ & 2.12 & $(0.68,6.61)$ \\
\hline \multirow{3}{*}{$\begin{array}{l}\text { Health care } \\
\text { satisfaction (past } \\
\text { year) }\end{array}$} & Very satisfied & 1.00 & 1.00 & & 1.00 & & 1.00 & 1.00 & & 1.00 & \\
\hline & Somewhat sat. & 1.00 & 0.97 & $(0.76,1.25)$ & 0.99 & $(0.77,1.28)$ & 1.69 & 1.69 & $(0.73,3.90)$ & 1.55 & $(0.65,3.72)$ \\
\hline & Not satisfied & 1.38 & 1.31 & $(0.93,1.84)$ & 1.25 & $(0.88,1.78)$ & 2.81 & 2.38 & $(0.92,6.16)$ & 1.96 & $(0.72,5.32)$ \\
\hline \multirow{3}{*}{$\begin{array}{l}\text { Quality of MD } \\
\text { care (past year) }\end{array}$} & Excellent & 1.00 & 1.00 & & 1.00 & & 1.00 & 1.00 & & 1.00 & \\
\hline & Good & 1.24 & 1.27 & $(0.96,1.68)$ & 1.23 & $(0.92,1.63)$ & 1.17 & 1.36 & $(0.32,5.82)$ & 1.66 & $(0.39,7.06)$ \\
\hline & Fair or poor & 2.16 & 2.21 & $(1.41,3.47)$ & 2.25 & $(1.42,3.58)$ & 1.41 & 1.36 & $(0.28,6.57)$ & 1.47 & $(0.35,6.19)$ \\
\hline \multirow{3}{*}{$\begin{array}{l}\text { Satisfaction of } \\
\text { MD care (past } \\
\text { year) }\end{array}$} & Very satisfied & 1.00 & 1.00 & & 1.00 & & 1.00 & 1.00 & & 1.00 & \\
\hline & Somewhat sat. & 1.17 & 1.16 & $(0.87,1.56)$ & 1.17 & $(0.87,1.58)$ & 1.12 & 1.10 & $(0.23,5.33)$ & 1.18 & $(0.23,5.98)$ \\
\hline & Not satisfied & 1.83 & 1.72 & $(I .09,2.7 I)$ & 1.65 & $(1.02,2.66)$ & 1.76 & 1.56 & $(0.30,8.05)$ & 1.51 & $(0.35,6.46)$ \\
\hline
\end{tabular}

* Estimated effects adjusted for age (18-44, 45-64, 65+ years), sex, and race/ethnicity (white only, other/multiple races or ethnicities).

tEstimated effects adjusted for age (18-44, 45-64, 65+ years), sex, race/ethnicity (white only, other/multiple races or ethnicities), education (no high school degree, high school degree or GED, some college, 4-year college degree or certificate), main source of income (employment, other sources), and health-related quality of life (Health Utility Index score [continuous]).

¥Odds ratio not shown because of singularities in data for fitting model.

$\mathrm{OR}=$ odds ratio; $\mathrm{Cl}=$ confidence interval; $\mathrm{GP}=$ general practitioner or family doctor; $\mathrm{DC}=$ Doctor of Chiropractic; HUI = Health Utility Index;

$\mathrm{CHD}=$ coronary heart disease; $\mathrm{MD}=$ medical doctor. 
Major strengths of the study are the population-based design covering two countries and several nationalities, survey administration in three languages using a standard approach across countries, the CATI method of questionnaire administration, the comprehensive set of previously validated measures encompassing multiple dimensions (e.g., health status, chronic conditions, activity restrictions, socioeconomic and demographic information, lifestyle factors, use of and access to health-care services, perceptions of health-care quality and satisfaction), use of several sets of multivariable models to control for potential confounding and to assess sensitivity of estimates, and methods allowing findings to be generalized to the U.S. and Canada. Quality assurance measures, including use of skilled interviewers, observations of interviewers, use of procedures to ensure that data errors were minimized, and coding and edit quality checks to verify processing logic were employed to reduce non-sampling errors [19].

Our findings should be considered in light of several limitations. Despite taking into account non-response in the analyses, the relatively low response rates may have introduced selection bias because of possible differences between respondents and nonrespondents. We do not have any data on which to compare these two groups and estimate the magnitude of the bias, if any. All data were self reported and no attempts were made to verify the accuracy of the reports, either through direct observation or via independent sources. Bias resulting from inaccurate recall or dishonesty may have occurred. Residual confounding is another source of possible bias. We used multivariable modeling to control for the effects of several variables; however, confounding cannot be ruled out. For example, population density and geographic area, which have been shown previously to be associated with care seeking $[10,13,15,33]$, are not included in the survey and thus could not be considered analytically as either predictors of use or confounders of other exposure effects. Because the study is cross sectional in nature and many of the variables are time dependent, the temporal relations between several of the potential predictors and pattern of health-care use cannot be determined. The study also does not allow for inferences regarding care-seeking for specific conditions, or the effects of care seeking on clinical, cost, and other outcomes. Finally, estimates at the state and provincial levels are not possible, and because of small numbers of persons seeking care from chiropractors alone, some parameters were not estimable or estimated imprecisely.

\section{Conclusion}

Chiropractic and general practitioner patients are quite dissimilar within both Canada and the U.S., and notable between-country differences in GP and DC patients are apparent as well. Such individual and geographic varia- tions have broad and potentially far-reaching implications for patients, providers, policymakers, and researchers. Our findings should be considered when interpreting observational studies of chiropractic and medical care utilization and outcomes, and would be useful in the design of longitudinal studies to test specific hypotheses regarding individual and societal-level predictors and consequences of (a) chiropractic vs. primary medical care and (b) the integration of chiropractic with medical care in North America and elsewhere.

\section{Competing interests}

The author(s) declare that they have no competing interests.

\section{Authors' contributions}

ELH conceived of the study, developed the objectives, reviewed the literature, supervised the analysis, and drafted the manuscript. L-MC performed the statistical analysis and helped to draft part of the manuscript. Both authors read and approved the final manuscript.

\section{References}

I. Druss BG, Rosenheck RA: Association between use of unconventional therapies and conventional medical services. JAMA 1999, 282:65I-6.

2. Hing E, Middleton K: National Hospital Ambulatory Medical Care Survey: 2002 outpatient department summary. Adv Data Vital Health Stat :345. June 24, 2004

3. Barnes PM, Powell-Griner E, McFann K, Nahin RL: Complementary and alternative medicine use among adults: United States, 2002. Adv Data Vital Health Stat :343. May 27, 2004

4. Wolsko PM, Eisenberg DM, Davis RB, Kessler R, Phillips RS: Patterns and perceptions of care for treatment of back and neck pain: results of a national survey. Spine 2003, 28:292-7.

5. Hertzman-Miller RP, Morgenstern H, Hurwitz EL, Yu F, Adams AH, Harber P, Kominski GF: Comparing the satisfaction of lowback-pain patients randomized to receive medical or chiropractic care: Results from the UCLA Low-Back Pain Study. Am J Public Health 2002, 92: I628-33.

6. Drivdahl CE, Miser WF: The use of alternative health care by a family practice population. J Am Board Fam Pract 1998, I I: I93-9.

7. Palinkas LA, Kabongo ML, San Diego Unified Practice Research in Family Medicine Network: The use of complementary and alternative medicine by primary care patients. A SURF*NET study. J Fam Pract 2000, 49: I I 2 I-30.

8. Eisenberg DM, Davis RB, Ettner SL, Appel S, Wilkey S, Van Rompay $M$, Kessler RC: Trends in alternative medicine use in the United States, 1990-1997: Results of a follow-up national survey. JAMA 1998, 280: I569-75.

9. Eisenberg DM, Kessler RC, Van Rompay MI, Kaptchuk TJ, Wilkey SA, Appel S, Davis RB: Perceptions about complementary therapies relative to conventional therapies among adults who use both: results from a national survey. Ann Intern Med 2001 , I35:344-5I.

10. Deyo RA, Tsui-Wu YJ: Descriptive epidemiology of low-back pain and its related medical care in the United States. Spine 1987, I 2:264-8.

II. Shekelle PG, Markovich M, Louie R: Factors associated with choosing a chiropractor for episodes of back pain care. Med Care 1995, 33:842-50.

12. Carey TS, Evans A, Hadler N, Kalsbeek W, McLaughlin C, Fryer J: Care-seeking among individuals with chronic low back pain. Spine 1995, 20:312-7.

13. Hurwitz EL, Morgenstern H: The effects of comorbidity and other factors on medical versus chiropractic care for back problems. Spine 1997, 22:2254-64. 
14. Hurwitz EL, Morgenstern H: The effect of comorbidity on care seeking for back problems in the United States. Annals Epidemiol 1999, 9:262-70.

15. Cote P, Cassidy JD, Carroll L: The treatment of neck and low back pain: Who seeks care? Who goes where? Med Care 200I, 39:956-67.

16. Schoen C, Osborn R, Huynh PT, Doty M, Davis K, Zapert K, Peugh J: Primary care and health system performance: Adults' experiences in five countries. Health Affairs - Web Exclusive [http:// content.healthaffairs.org/cgi/content/abstract/hlthaff.w4.487]. October 28, 2004, DOI 10.1377/hlthaff.W4.487: (accessed 3/19/2005).

17. Starfield B, Shi L, Grover A, Macinko J: The effects of specialist supply on populations' health: Assessing the evidence. Health Affairs B Web Exclusive [http://content.healthaffairs.org/cgi/content/ abstract/hlthaff.w5.97]. March I5, 2005, DOI 10.1377/hlthaff.W5.97, (accessed 3/19/2005).

18. Joint Canada/United States Survey of Health [http://www.cdc.gov/nchs/ about/major/nhis/jcush mainpage.htm]. National Center for Health Statistics of the United States Centers for Disease Control and Prevention (accessed 9/26/2004)

19. Joint Canada/United States Survey of Health Public Use Microdata File User

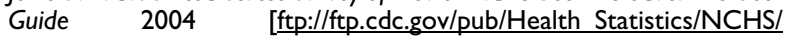
Dataset Documentation//CUSH/]. Statistics Canada and the United States National Center for Health Statistics (accessed 9/26/2004).

20. 1996 Census of Population Ottawa: Statistics Canada; 1996.

21. Current Population Survey: United States Department of Commerce, Economics and Statistics Division, Bureau of the Census; 2002.

22. Composite International Diagnostic Interview [http://www.who.int/msa/ cidi/index.htm]. (accessed 10/28/2004).

23. American Psychiatric Association: Diagnostic and Statistical Manual of Mental Disorders Third rev edition. Washington, DC: American Psychiatric Association; 1987.

24. National Comorbidity Survey [http://www.hcp.med.harvard.edu/ncs/] (accessed 10/28/2004).

25. Furlong WJ, Feeny DH, Torrance GW: Health Utilities Index (HUI): Algorithm for determining HUI Mark 2 (HUI2)/ Mark 3 (HUI3) health status classification levels, health states, health-related quality of life utility scores and single sttribute utility score from 40-item interviewer-administered health status questionnaires. Dundas, Canada: Health Utilities Inc; 1999.

26. Canadian Guidelines for Body Weight Classification in Adults, Health Canada $2003 \quad$ [http://www.hc-sc.gc.ca/hpfb-dgpsa/onpp-bppn/ weight book e.pdf]. (accessed 10/28/2004).

27. Canadian Fitness and Lifestyle Research Institute [http:// www.cflri.ca]. (accessed 10/28/2004).

28. Ainsworth BE, Haskell WL, Whitt MC, et al:: Compendium of physical activities: an update of activity codes and MET intensities. Med Sci Sports Exerc 2000, 32(Suppl):S498-504

29. Campbell Survey on Well-Being in Canada [http://www.cflri.ca/cflri/pa/ surveys/88survey.html]. (accessed 10/28/2004).

30. Ontario Health Survey [http://www.chass.utoronto.ca/datalib/code books/utm/ohs/ohs90.htm]. (accessed 10/28/2004).

31. SAS Institute Inc: The SAS System for Windows 8.I Cary, North Carolina: SAS Institute Inc; 2000.

32. Shah BV, Barnwell BG, Bieler GS: SUDAAN User's Manual, Release 7.5 Research Triangle Park, NC: Research Triangle Institute; 1997.

33. Hurwitz EL, Coulter ID, Adams AH, Genovese BJ, Shekelle PG: Use of chiropractic services from 1985 through 1991 in the United States and Canada. Am J Public Health |998, 88:77|-6.

34. Christensen MG, Kollasch MW: Job Analysis of Chiropractic 2005: A project report, survey analysis and summary of the practice of chiropractic within the United States 2005 [http://www.nbce.org/publications/ pub analysis chap.html]. Greeley, CO: National Board of Chiropractic Examiners (Accessed 3/30/2005).

35. Hawk C, Long CR, Perillo M, Boulanger KT: A survey of US chiropractors on clinical preventive services. I Manipulative Physiol Ther 2004:287-98.

36. Coulter ID, Hurwitz EL, Adams AH, Genovese BJ, Hays R, Shekelle PG: Patients using chiropractors in North America: Who are they, and why are they in chiropractic care. Spine 2002 , 27:291-8.

37. Smith M, Carber L: Chiropractic health care in health professional shortage areas in the United States. Am J Public Health 2002, 92:2001-9.
38. Meeker WC, Haldeman S: Chiropractic: a profession at the crossroads of mainstream and alternative medicine. Ann Intern Med 2002, I36:216-27.

39. Duenas R, Carucci GM, Funk MF, Gurney MW: Chiropractic B primary care, neuromusculoskeletal care, or musculoskeletal care? Results of a survey of chiropractic college presidents, chiropractic organization leaders, and Connecticut-licensed doctors of chiropractic. J Manipulative Physiol Ther 2003, 26:510-23.

40. Cooper RA, McKee HJ: Chiropractic in the United States: trends and issues. Milbank Quarterly 2003, 81 : I07-38.

4I. Legorreta AP, Metz RD, Nelson CF, Ray S, Chernicoff HO, DiNubile NA: Comparative analysis of individuals with and without chiropractic coverage: Patient characteristics, utilization, and costs. Arch Intern Med 2004, I 64:1985-92.

42. Ness J, Nisly N: Cracking the problem of back pain: Is chiropractic the answer? Arch Intern Med 2004, I 64:1953-4.

43. Sarnat RL, Winterstein J: Clinical and cost outcomes of an integrative IPA. J Manipulative Physiol Ther 2004, 27:336-47.

44. Consultation on Identity: Quantitative Research Findings [http:// www.wfc.org/doc uploads/WFC\%20Report January\%2052005.pps] World Federation of Chiropractic and Northstar Research Partners December 7, 2004: (accessed 3/26/2005).

45. Marmot M: Social determinants of health inequalities. Lancet 2005, 365: 1099-I I04.

46. Pedersen $\mathrm{P}$, Kleberg $\mathrm{P}$, Walker $\mathrm{K}$ : A pilot survey of patients and chiropractors in European chiropractic practices: sociodemographics, anamnestic, and management procedures. Eur J Chiropractic 1993, 41:5-19.

47. Ebrall P: A descriptive report of the case-mix within Australian chiropractic practice. Chir J Aust 1993, 23:92-7.

48. Rubinstein S, Pfeifle CE, van Tulder MW, Assendelft WJJ: Chiropractic patients in the Netherlands: a descriptive study. J Manipulative Physiol Ther 2000, 23:557-63.

49. Hartvigsen J, Sorensen LP, Graesborg K, Grunnet-Nilsson N: Chiropractic patients in Denmark: a short description of basic characteristics. I Manipulative Physiol Ther 2002, 25: 162-7.

50. Vinci C, Peterson CK: A pilot survey of chiropractic in Italy. Eur J Chiropractic 2003, 47:61-78.

51. Wilson FJH: A survey of chiropractors in the United Kingdom. Eur J Chiropractic 2003, 50: 185-98.

52. Shekelle PG, Brook RH: A community-based study of the use of chiropractic services. Am J Public Health I991, 81:439-42.

53. Hurwitz EL: The relative impact of chiropractic vs. medical management of low back pain on health status in a multispecialty group practice. J Manipulative Physiol Ther 1994, I 7:74-82.

54. Hurwitz EL, Morgenstern H, Yu F: Cross-sectional and longitudinal associations of low-back pain and related disability with psychological distress among patients enrolled in the UCLA Low-Back Pain Study. J Clinical Epidemiology 2003, 56:463-7I.

55. Carroll LJ, Cassidy JD, Cote P: Depression as a risk factor for onset of an episode of troublesome neck and low back pain. Pain 2004, 107:134-9.

56. Hurwitz EL, Morgenstern $\mathrm{H}$ : Cross-sectional associations of asthma, hay fever, and other allergies with major depression and low-back pain among adults aged 20-39 years in the United States. Am J Epidemiol 1999, I 50: I I07-I6.

\section{Pre-publication history}

The pre-publication history for this paper can be accessed here:

http://www.biomedcentral.com/1472-6963/6/49/prepub 